\title{
Gold and Ceria as Catalysts for VOC Abatement: A Review
}

\author{
Jana Gaálová and Pavel Topka *(D)
}

check for

updates

Citation: Gaálová, J.; Topka, P. Gold and Ceria as Catalysts for VOC Abatement: A Review. Catalysts 2021, 11, 789. https://doi.org/10.3390/ catal11070789

Academic Editor: Stefano Cimino

Received: 1 June 2021

Accepted: 26 June 2021

Published: 29 June 2021

Publisher's Note: MDPI stays neutral with regard to jurisdictional claims in published maps and institutional affiliations.

Copyright: (c) 2021 by the authors. Licensee MDPI, Basel, Switzerland. This article is an open access article distributed under the terms and conditions of the Creative Commons Attribution (CC BY) license (https:// creativecommons.org/licenses/by/ $4.0 /)$.
Institute of Chemical Process Fundamentals of the Czech Academy of Sciences, Rozvojová 135, 16502 Praha, Czech Republic; gaalova@icpf.cas.cz

* Correspondence: topka@icpf.cas.cz; Tel.: +420-220-390-288

\begin{abstract}
Due to its excellent oxygen storage capacity, ceria is a well-known oxidation catalyst. However, its performance in the oxidation of volatile organic compounds can be improved by the introduction of gold. Depending on the type of VOC to be oxidized, the surface of gold nanoparticles and the gold/ceria interface may contribute to enhanced activity and/or selectivity. Choosing a proper preparation method is crucial to obtain optimal gold particle size. Deposition-precipitation was found to be more suitable than coprecipitation or impregnation. For industrial applications, monolithic catalysts are needed to minimize the pressure drop in the reactor and reduce mass and heat transfer limitations. In addition to the approach used with powder catalysts, the method employed to introduce gold in/on the washcoat has to be considered.
\end{abstract}

Keywords: volatile organic compounds; $\mathrm{Au} ; \mathrm{CeO}_{2} ; \mathrm{VOC}$ total oxidation; noble metal catalysts

\section{Introduction}

Volatile organic compounds (VOCs) are organic compounds having an initial boiling point of less than $250{ }^{\circ} \mathrm{C}$ measured at a standard atmospheric pressure of $101.3 \mathrm{kPa}$, which participate in atmospheric photochemical reactions [1].

VOCs are harmful to the environment and human health. They are emitted into the atmosphere from thousands of sources and recognized as one of the major factors responsible for the increase in global air pollution. They can also react with $\mathrm{NO}_{x}$ and oxygen to form ozone: $\mathrm{VOC}+\mathrm{NO}_{x}+\mathrm{O}_{2}+h v \rightarrow \mathrm{O}_{3}+$ other products. Ozone causes human health problems, affects DNA and enzyme functions, is toxic for vegetation, and impairs the quality of some materials. Therefore, an abatement of VOC emissions is considered desirable. Anthropogenic VOC emissions are regulated by law [2].

The best available techniques for reducing VOC emissions include the measures focusing on process design (primary measures) and post-process removal (secondary measures) [3]. Among secondary measures, catalytic oxidation is the most effective for low concentrations of VOCs [1,3-9]. It is an efficient, cost-effective and environmentally sound way to treat these harmful emissions $[10,11]$. The mechanism of total catalytic oxidation depends on the type of catalytic material used. Two types of catalysts are employed for oxidation reactions [3]: (i) metal oxides and (ii) noble metals (supported or not).

Metal oxide catalysts (in particular $\mathrm{Cu}, \mathrm{Mn}, \mathrm{Cr}, \mathrm{Co}, \mathrm{Mn}, \mathrm{Ni}$, Mo and $\mathrm{V}$ oxides) show appreciable activity; they are cheap but not sufficiently stable [12-16]. In general, noble metal catalysts possess greater activity than oxide catalysts, contributing to the reduction of operating costs despite their higher manufacturing cost. Their catalytic activity depends on the noble metal and varies with the nature of VOC [17]. The mainstream of commercial catalysts belongs to this group and consists of Pt or Pd or both, supported on high-surfacearea $\gamma-\mathrm{Al}_{2} \mathrm{O}_{3}$ [3,18-27]. Palladium or bimetallic Pt-Pd active phase supported on alumina or $\mathrm{CeO}_{2}-\mathrm{Al}_{2} \mathrm{O}_{3}$ mixed oxides are still probably the most studied group of catalysts [28-30].

For a long time, the noticeable exception of noble metals was gold. Au, in the bulk form, is considered the most noble of all metals [31]. The low adsorption energy of gases and high energy barriers for their dissociation disadvantage reactivity on gold. Thus, for 
years, it was also the most abundant noble metal in catalysis. Nowadays, gold-based catalysts attract increasing attention [32]. They have proved a beneficial role in various catalytic reactions of commercial and environmental status, e.g., exhaust gas purification, oxidation of glucose, water gas shift, $\mathrm{CO}$ oxidation, water or hydrogen purification, air cleaning, fuel cells and VOC oxidation.

\section{Gold Catalysts for VOC Oxidation}

The preparation of Au catalysts for VOC oxidation has been widely investigated. The studies on reaction mechanisms enhance the understanding of the oxidation process using Au catalysts [33]. To achieve the best performance of the catalyst in the oxidation process, diverse approaches to design the gold catalysts have been applied. The preparation method, the loading of gold, the nature of VOC to be oxidized are just some of them [34-38].

According to many authors, the role of support is crucial. It contributes to the control of the final amount, the size and the shape of gold particles, influencing the activity of material in VOC oxidation. Typically, different oxide supports are employed, e.g., oxides of iron [39-47], titan [48-54], aluminum [55-57], vanadium [58-60], manganese [61,62] or cobalt [56,63-66]. Figure 1 shows the example of gold nanoparticles supported on ceria-zirconia mixed oxide. According to Scirèand Liotta [67], VOC deep oxidation over $\mathrm{Au} /$ metal oxide catalysts is governed by both the support and gold properties, which often amplify their effects due to a synergistic action. However, there is still debate on how different variables affect support and gold properties and thus the catalytic performance.

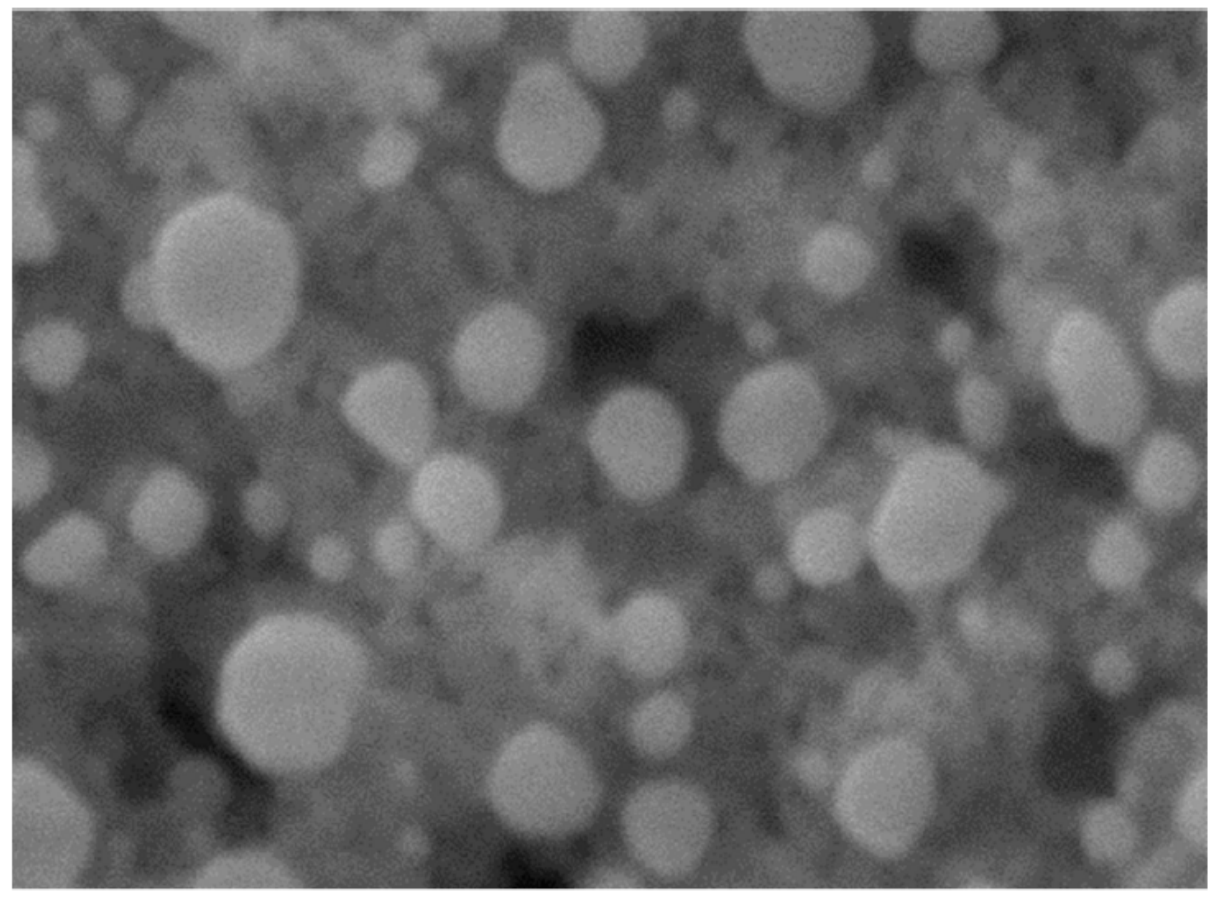

Figure 1. The TEM image of the $\mathrm{Au} / \mathrm{Ce}_{0.5} \mathrm{Zr}_{0.5} \mathrm{O}_{2}$ powder catalyst prepared by impregnation studied in Ref. [68].

A real catalyst usually contains several components, and its surface composition and structure may change during the catalytic process. Corma's group [69] reported that extremely low concentrations of mononuclear gold complexes in impregnation solution resulted in catalytically active gold clusters (TOF ca. $10^{7}$ ). Thus, new properties of supported gold catalysts can be reached using nanometer and sub-nanometer structures [70]. Recently, the group of Keiski showed that $\mathrm{Au} / \mathrm{Al}_{2} \mathrm{O}_{3}$ was more active and selective to $\mathrm{HCl}$ in dichloromethane oxidation than the $\mathrm{Pt} / \mathrm{Al}_{2} \mathrm{O}_{3}$ catalyst due to small Au particle size $(\sim 5 \mathrm{~nm})$ with narrow size distribution $( \pm 5 \mathrm{~nm})$ and good metal dispersion [71]. 
It is possible to modify the monometallic gold catalyst by adding a second metal to improve the dispersion, adsorption and activity towards the oxidation of hydrocarbons [72] For example, neighboring Pd atoms change Au's electronic structure, leading to high activity. Preparation and characterization of the bimetallic catalysts containing Pt and $\mathrm{Au}$ for VOC oxidation were studied by Kim et al. [73]. Influence of $\mathrm{Pt}-\mathrm{Au}$ molar ratio on the catalytic activity for toluene oxidation revealed that $\mathrm{Pt}_{75} \mathrm{Au}_{25}$ and $\mathrm{Pt}_{67} \mathrm{Au}_{33}$ catalysts concurrently coated with Pt and Au precursors by impregnation method showed higher activity than monometallic Pt and Au catalyst for toluene oxidation. Kim et al. also studied $\mathrm{Au}_{0.5} \mathrm{Ag}_{0.5}$ alloy films and highlighted that VOCs affect only the surfaces of metal nanoparticles [74]. Noble metals (Pd, $\mathrm{Au}$ ) were deposited onto macro-mesoporous metaloxide supports to form mono and bimetallic catalysts by Barakat et al. [75]. The catalytic materials were tested in the oxidation of selected VOCs. PdAu/ $\mathrm{TiO}_{2}$ and $\mathrm{PdAu} / \mathrm{TiO}_{2}-\mathrm{ZrO}_{2}$ $80 / 20$ catalysts demonstrated the best activity and life span in the oxidation of toluene and propene; the lowest coke content after catalytic testing was observed for them too. An effective method of enhancing catalytic activity is the core-shell construction of nanosized bimetallic particles [76]. The Au-Pd is one of the core-shell systems that have gained considerable attention $[53,77]$.

\section{3. $\mathrm{CeO}_{2}$ and Ceria-Supported Noble Metal Catalysts for VOC Oxidation}

Cerium oxide can be used as a catalyst or an active phase/support of more complex catalytic material for VOCs oxidation. However, ceria is rarely used alone in the oxidation process [78], usually for the matter of comparison [79,80]. The possibilities of mixed oxides forms [81,82] and combining ceria with other metals (noble or other supported metals [30,83]) are multiples, as demonstrated in the selected publications gathered in Table 1 (excluding gold catalysts, which are included in Table 2). The nature of catalytic components, how they influence each other, a preparation process, and many others determine the properties of final catalysts; e.g., a preference of reduced centers for surface positions, stability and activity in the oxidation of different VOCs, etc.

The study of Pitkäaho et al. [84] reports total oxidation of perchloroethylene over Pt, $\mathrm{Pd}$, $\mathrm{Rh}$ and $\mathrm{V}_{2} \mathrm{O}_{5}$ metallic monolith catalysts supported on $\mathrm{Al}_{2} \mathrm{O}_{3}, \mathrm{CeO}_{2}$ and $\mathrm{TiO}_{2}$-doped $\mathrm{Al}_{2} \mathrm{O}_{3}$. It shows that the redox properties of the catalyst and the amount of activated oxygen may play a bigger role than the acidity in the oxidation of certain VOCs.

Table 1. Recently studied ceria-based catalysts for VOCs oxidation.

\begin{tabular}{|c|c|c|c|c|}
\hline \multirow{2}{*}{ 1st Author, Publ. Year } & \multirow{2}{*}{ Ref. } & \multicolumn{2}{|c|}{ Catalyst Containing } & \multirow{2}{*}{ VOCs to Oxidize } \\
\hline & & Noble Metal & Ce and: & \\
\hline Zheng, 2021 & [85] & $\mathrm{Pt}$ & - & Benzene \\
\hline Zeng, 2021 & {$[86]$} & - & $\mathrm{Cu}$ & Toluene \\
\hline Jiang, 2020 & [87] & $\mathrm{Pt}$ & - & Methanol \\
\hline $\mathrm{Li}, 2020$ & [88] & - & Co & Methanol, Acetone, Toluene, O-xylene \\
\hline Sophiana, 2020 & [89] & & $\mathrm{Cu}, \mathrm{Mn}, \mathrm{Ni}, \mathrm{Zr}$ & Benzene \\
\hline Al-Aani, 2020 & [90] & - & $\mathrm{Cu}, \mathrm{Mg}, \mathrm{Al}$ & Methane \\
\hline Figueredo, 2020 & [91] & - & $\mathrm{Mn}, \mathrm{Cu}$ & Ethylene, Propylene \\
\hline Jiang, 2020 & [92] & - & $\mathrm{Fe}$ & Toluene \\
\hline Zheng, 2020 & [93] & - & Co & Acetone \\
\hline Jiang, 2019 & [94] & - & $\mathrm{Mn}$ & Ethyl acetate \\
\hline Wang, 2019 & [95] & - & $\mathrm{Cu}$ & Methanol, Acetone, Toluene, O-xylene \\
\hline Genty, 2019 & [96] & - & $\mathrm{Co}, \mathrm{Al}$ & Toluene \\
\hline Shah, 2019 & [97] & - & $\mathrm{Zr}$ & Propane, Naphthalene \\
\hline Chen, 2019 & [98] & $\mathrm{Pd}-\mathrm{Pt}$ & $\mathrm{Al}$ & Benzene \\
\hline Gołabek, 2019 & [99] & - & zeolite $\beta$ & Trichloroethylene \\
\hline Okal, 2018 & [100] & - & $\mathrm{Ru}$ & Iso-butane, N-butane, Propane \\
\hline Hosseini, 2017 & [101] & $\mathrm{Pd}$ & Al-clinoptilolite & Toluene \\
\hline
\end{tabular}


Table 1. Cont.

\begin{tabular}{|c|c|c|c|c|}
\hline \multirow{2}{*}{ 1st Author, Publ. Year } & \multirow{2}{*}{ Ref. } & \multicolumn{2}{|c|}{ Catalyst Containing } & \multirow{2}{*}{ VOCs to Oxidize } \\
\hline & & Noble Metal & Ce and: & \\
\hline Konsolakis, 2017 & [102] & - & Co & Ethyl acetate \\
\hline Piumetti, 2017 & [103] & - & $\mathrm{Cu}$ & Ethylene \\
\hline Saedy, 2017 & [104] & - & $\mathrm{Al}$ & Toluene \\
\hline Issa, 2017 & [105] & - & $\mathrm{Ti}$ & Ethyl acetate \\
\hline He, 2016 & [106] & - & $\mathrm{Y}, \mathrm{Sm}, \mathrm{La}$ & Methanethiol \\
\hline Carabineiro, 2016 & [107] & - & $\mathrm{Gd}, \mathrm{La}, \mathrm{Pr}, \mathrm{Nd}, \mathrm{Sm}$ & Ethyl acetate \\
\hline Topka, 2016 & [108] & $\mathrm{Pt}$ & $\mathrm{Zr}$ & Ethanol, Toluene \\
\hline Dinh, 2015 & [109] & - & $\mathrm{Mn}$ & Trichloroethylene \\
\hline $\begin{array}{l}\text { Abdelouahab-Reddam, } \\
2015\end{array}$ & [110] & $\mathrm{Pt}$ & $\mathrm{C}$ & Ethanol \\
\hline Xue, 2015 & [111] & - & $\mathrm{Y}, \mathrm{Zr}$, montmorillonite & Acetone, Toluene, Ethyl acetate \\
\hline Yosefi, 2015 & [112] & - & $\mathrm{Cu}$, clinoptilolite & Toluene \\
\hline Nousir, 2015 & [113] & - & $\mathrm{Zr}$ & Ethyl acetate \\
\hline Yang, 2014 & [114] & - & $\mathrm{Cr}$ & 1,2-dichloroethane \\
\hline Deng, 2014 & [115] & - & $\mathrm{Cu}, \mathrm{Zr}$ & Toluene \\
\hline Perez, 2014 & [116] & - & $\mathrm{Co}, \mathrm{Mg}, \mathrm{Al}$ & Toluene \\
\hline Sedjame, 2014 & [83] & $\mathrm{Pt}$ & $\mathrm{Al}$ & N-butanol, Acetic acid \\
\hline Urbutis, 2014 & [117] & - & $\mathrm{Cu}, \mathrm{NaX}$ & Benzene, Toluene, O-xylene \\
\hline Barakat, 2014 & & & $\mathrm{Fe}, \mathrm{Ni}, \mathrm{Ti}$ & Toluene \\
\hline Ozawa, 2013 & [81] & - & $\mathrm{Zr}$ & Toluene \\
\hline Konsolakis, 2013 & [118] & - & $\mathrm{Cu}, \mathrm{Sm}$ & Ethyl acetate \\
\hline Yue, 2013 & [119] & $\mathrm{Pd}$ & ZSM 5 & Methyl ethyl ketone \\
\hline Dziembaj, 2013 & [120] & - & $\mathrm{Cu}$ & Methanol, Acetone \\
\hline Shi, 2012 & [121] & $\mathrm{Ag}$ & $\mathrm{Mn}$ & Formaldehyde \\
\hline Pitkäaho, 2012 & [84] & $\mathrm{Pt}, \mathrm{Pd}, \mathrm{Rh}$ & $\mathrm{Al}, \mathrm{Ti}, \mathrm{V}$ & Perchloroethylene \\
\hline Matějová, 2012 & [122] & $\mathrm{Pt}, \mathrm{Pd}$ & $\mathrm{Al}$ & Dichloromethane, Toluene, Ethanol \\
\hline Aranda, 2012 & [80] & - & $\mathrm{Cu}$ & Naphthalene \\
\hline Abbasi, 2011 & [123] & $\mathrm{Pt}$ & $\mathrm{Al}$ & Toluene \\
\hline Pérez, 2011 & [124] & - & $\mathrm{Al}, \mathrm{Co}, \mathrm{Cu}, \mathrm{Mg}, \mathrm{Pr}$ & Ethanol \\
\hline Weng, 2011 & [125] & - & $\mathrm{Cr}, \mathrm{Cu}, \mathrm{Mn}, \mathrm{Ti}$ & Toluene \\
\hline Mayernick, 2011 & [126] & $\mathrm{Pd}$ & - & Methane \\
\hline Liao, 2011 & [127] & - & $\mathrm{Al}, \mathrm{La}, \mathrm{Mn}, \mathrm{Zr}$ & benzene \\
\hline He, 2011 & [78] & - & - & O-xylene \\
\hline Yu, 2010 & [128] & - & $\mathrm{Mn}, \mathrm{Ti}$ & Toluene \\
\hline Masui, 2010 & [129] & $\mathrm{Pt}$ & $\mathrm{Al}, \mathrm{Bi}, \mathrm{Zr}$ & Toluene \\
\hline Ferreira, 2010 & [130] & - & $\mathrm{Cu}$ & Methane \\
\hline Azalim, 2010 & [131] & - & $\mathrm{Mn}, \mathrm{Zr}$ & n-buthanol \\
\hline Puertolas, 2010 & [79] & - & $\begin{array}{l}\text { mesoporous siliceous } \\
\text { KIT-6 }\end{array}$ & Naphthalene \\
\hline Delimaris, 2008 & [132] & - & Mn & Ethyl acetate, ethanol, toluene \\
\hline Yan, 2008 & [133] & - & $\mathrm{Al}, \mathrm{Mn}, \mathrm{Y}, \mathrm{Zr}$ & benzene \\
\hline Zhi Min, 2007 & [134] & $\mathrm{Pt}$ & $\mathrm{Mn}, \mathrm{Y}, \mathrm{Zr}$ & Toluene \\
\hline Gutiérrez-Ortiz, 2004 & {$[82]$} & - & $\mathrm{Zr}$ & Aliphatic $\mathrm{C} 2$ chlorohydrocarbons \\
\hline
\end{tabular}


Similarly, Aranda et al. [80] reported that oxygen defects are the key parameter controlling the activity and selectivity of mesoporous copper-doped ceria for the total oxidation of naphthalene. In perchloroethylene oxidation, the $\mathrm{Pt} / \mathrm{Al}_{2} \mathrm{O}_{3}-\mathrm{CeO}_{2}$ and $\mathrm{Pd} / \mathrm{Al}_{2} \mathrm{O}_{3}-\mathrm{CeO}_{2}$ catalysts exhibited lower amounts of by-products (trichloroethylene, ethylene and $\mathrm{CO}$ ) than their analogues without ceria, confirming its positive effect also on the selectivity of the catalysts [84]. Sedjame et al. [83] showed that the addition of ceria to Pt catalysts leads to the formation of numerous intermediate products that have mainly been attributed to ceria-active sites. Nevertheless, this addition improves the catalytic performance for $n-$ butanol and acetic acid oxidations. The authors highlight that the catalytic activity of ceria depends on the nature of the VOCs. Recently, Li et al. [88] and Jiang et al. [94] confirmed the importance of oxygen vacancies that correlated with catalytic activity in the oxidation of different types of VOCs (Table 1).

\section{4. $\mathrm{Au} / \mathrm{CeO}_{2}$ Catalysts for VOC Oxidation}

Scirèet al. [135] studied the catalytic oxidation of volatile organic compounds over gold/cerium oxide catalysts. Catalytic combustion of 2-propanol, methanol and toluene was investigated over catalysts prepared by coprecipitation (CP) and deposition-precipitation (DP). DP has been found to be more suitable than CP to obtain highly active $\mathrm{Au} / \mathrm{CeO}_{2}$ catalysts because DP leads to gold nanoparticles, which are preferentially located on the surface of ceria [135]. The effect of the preparation method on the catalytic activity of $\mathrm{Au} / \mathrm{CeO}_{2}$ for VOC oxidation was also investigated by $\mathrm{Li}$ and $\mathrm{Li}$ [136]. The $\mathrm{Au} / \mathrm{CeO}_{2}$ catalysts were synthesized by $\mathrm{CP}, \mathrm{DP}$ and metallic colloids deposition (MCD) method, and tested in the total oxidation of toluene. The best results were obtained with $3 \mathrm{wt} . \% \mathrm{Au} / \mathrm{CeO}_{2}$ catalyst prepared by the DP method. The catalytic activity of $\mathrm{Au} / \mathrm{CeO}_{2}$ was related to the interaction between gold particles and supports, and the capability of gold particles to weaken the surface $\mathrm{Ce}-\mathrm{O}$ bonds adjacent to $\mathrm{Au}$ atoms. The $\mathrm{Ce}-\mathrm{O}$ bonds are weakened with the reduction of $\mathrm{Ce}^{4+}$ to $\mathrm{Ce}^{3+}$ (Figure 2) due to charge transfer to Ce during Au adsorption, which is accompanied by an electron charge transfer between the neutral metal atom and neighboring $\mathrm{Ce}^{4+}$ cation. Thus, the mobility of the surface lattice oxygen-involved in the VOC oxidation through a Mars-van Krevelen reaction mechanism-increases, which then leads to higher catalytic performance (Figure 3).

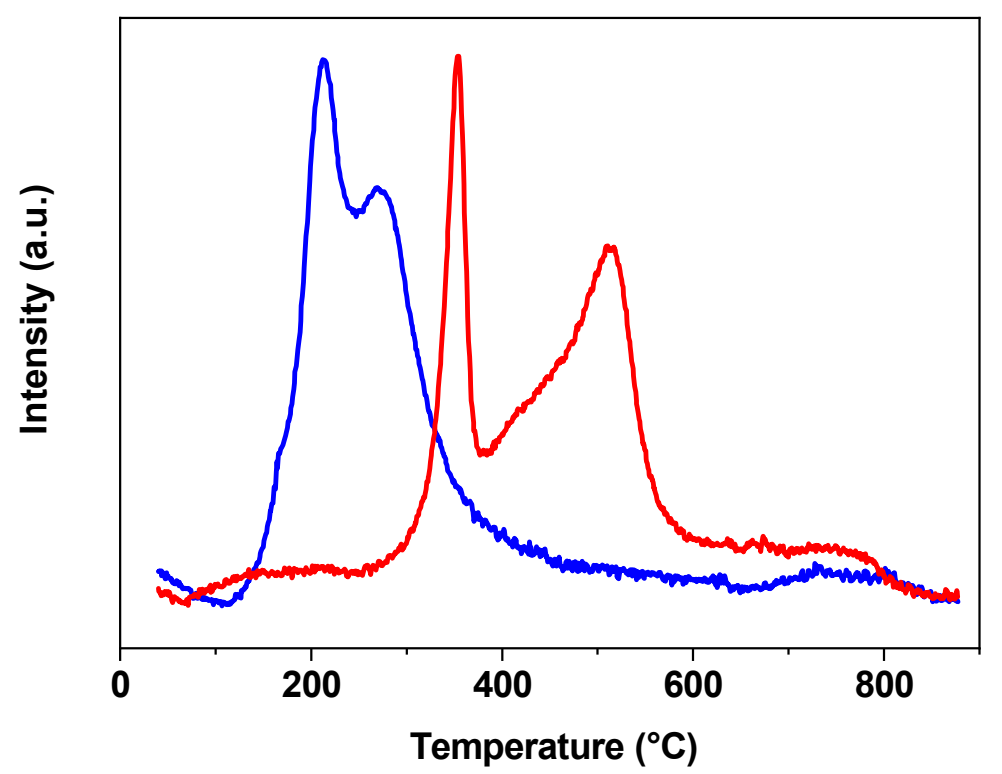

Figure 2. The improved reducibility of the $\mathrm{Au} / \mathrm{Ce}_{0.5} \mathrm{Zr}_{0.5} \mathrm{O}_{2}$ monolithic catalyst studied in Ref. [137] (blue) compared to the $\mathrm{Ce}_{0.5} \mathrm{Zr}_{0.5} \mathrm{O}_{2}$ monolithic catalyst (red) as shown by their $\mathrm{H}_{2}$-TPR profiles. 


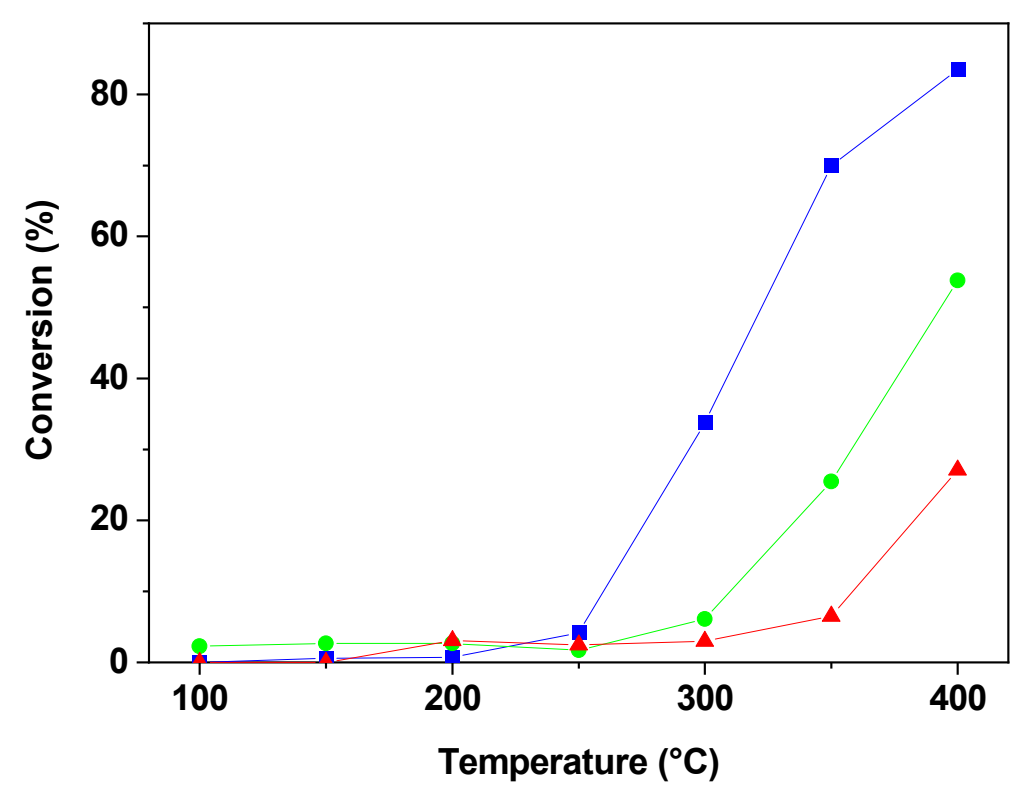

Figure 3. A shift of chlorobenzene conversion curve over the $\mathrm{Au} / \mathrm{Ce}_{0.5} \mathrm{Zr}_{0.5} \mathrm{O}_{2}$ powder catalysts studied in Ref. [138] with 0.3 wt.\% Au (green) and 2.8 wt.\% Au (blue) compared to the $\mathrm{Ce}_{0.5} \mathrm{Zr}_{0.5} \mathrm{O}_{2}$ support (red).

The importance of the interface between gold and ceria was underlined in the operando IR study of methanol oxidation [139]. The comparison of deposition-precipitation and impregnation method was studied by Aboukaïs et al. [140] for catalytic oxidation of propylene and toluene. They confirmed that the catalysts prepared by deposition-precipitation were more active than those prepared by impregnation due to the high number of gold nanoparticles and $\mathrm{Au}^{+}$species and the low concentration of $\mathrm{Cl}^{-}$ions present on its surface. Generally, the impregnation method requires the right choice of gold source and suitable treatment needed for preparing NPs; e.g., when popular source $\mathrm{HAlCl}_{4}$ is used, gold particles grow rapidly as a consequence of chlorine contamination. A better selection of gold source during impregnation can be $\mathrm{Au}\left(\mathrm{PPh}_{3}\right)\left(\mathrm{NO}_{3}\right)$, $\left[\mathrm{Au}_{9}\left(\mathrm{PPh}_{3}\right)_{8}\right]\left(\mathrm{NO}_{3}\right)_{3}$ or $\left[\mathrm{Au}_{6}\left(\mathrm{PPh}_{3}\right)_{6}\right]\left(\mathrm{BF}_{4}\right)_{2}$ [141]. Similar preparations can lead to catalytic material offering activities of a different magnitude. Precursor, methodology or support additives could be restrictive, and a more general approach is still needed [142].

Small gold nanoparticles (NPs $>5 \mathrm{~nm}$ in diameter) with homogeneous dispersions on the supports seem, so far, the most advantageous for catalytic activity. However, for a good understanding of the effects of gold particle size on catalytic properties, the samples with monodisperse size distributions are preferred; for $\mathrm{Au} / \mathrm{TiO}_{2}$ cathodic plasma deposition method was successfully used [143]. On the other hand, it should be noted that the contribution of large gold agglomerates to the catalytic activity in VOC oxidation was observed as well (Figure 3) [144]. High-resolution electron microscopy is crucial for estimating the size of Au nanoparticles (Figure 4). It should be noted that is difficult to distinguish $\mathrm{Au}$ supported on $\mathrm{CeO}_{2}$ in the TEM image mainly due to low diffraction contrast; HAADF-STEM is more suitable [141]. Moreover, every Au nanoparticle counted in the particle analysis should be confirmed by EDX (Figure 5). Examples of prepared Au catalysts containing ceria (and possibly other compounds) for VOC oxidation are listed in Table 2. The patent of Rhodia company on $\mathrm{Au} / \mathrm{CeO}_{2}-\mathrm{ZrO}_{2}$ catalysts for the treatment of tobacco smoke and polluted air is well known. 


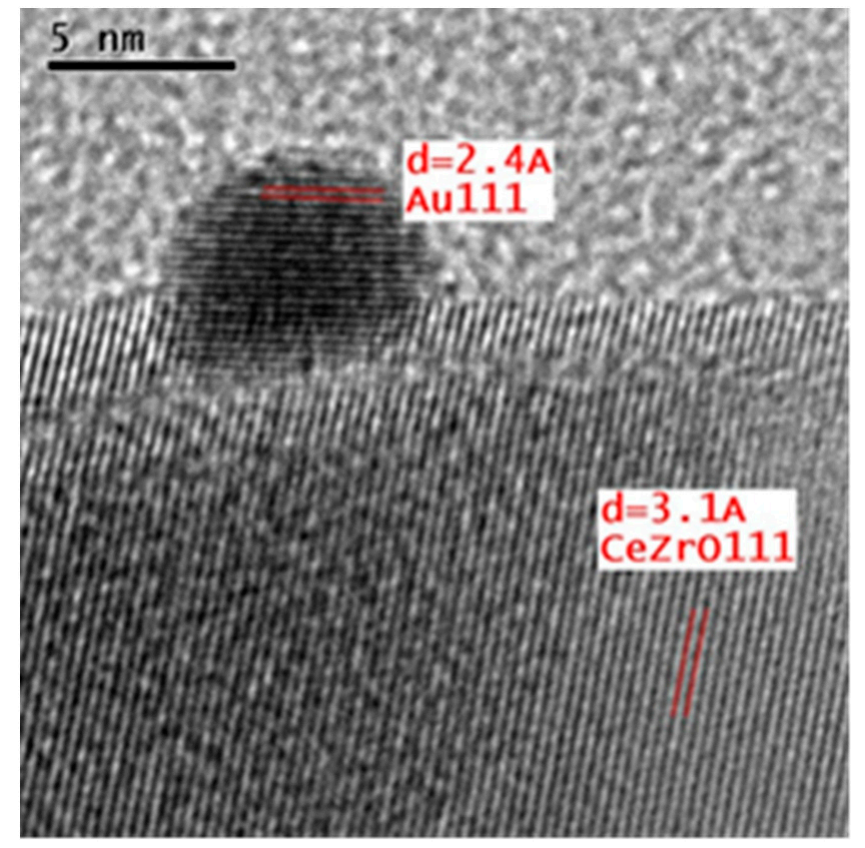

Figure 4. The identification of gold nanoparticles on the ceria-zirconia surface by the spacing of lattice fringes using HRTEM (the $\mathrm{Au} / \mathrm{Ce}_{0.5} \mathrm{Zr}_{0.5} \mathrm{O}_{2}$ monolithic catalyst studied in Ref. [137]).

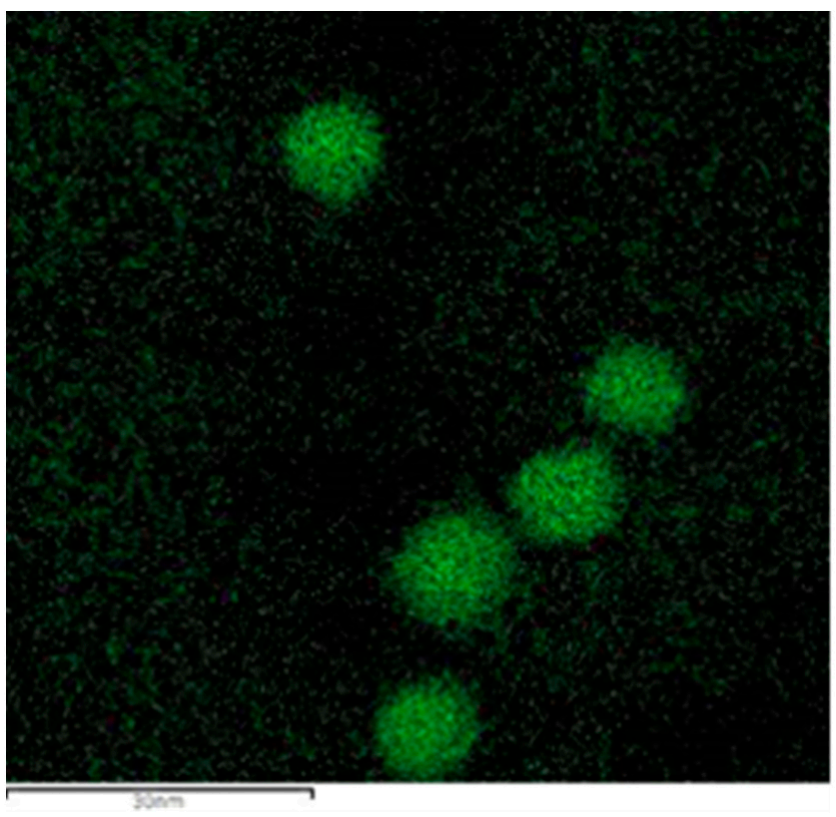

Figure 5. Confirmation of gold nanoparticles by EDX spectroscopy (the $\mathrm{Au} / \mathrm{Ce}_{0.5} \mathrm{Zr}_{0.5} \mathrm{O}_{2}$ monolithic catalyst studied in Ref. [137]). 
Table 2. Recently studied ceria-based Au catalysts for VOC oxidation.

\begin{tabular}{|c|c|c|c|c|}
\hline \multirow[b]{2}{*}{ 1st Author, Publ. Year } & \multirow[b]{2}{*}{ Ref. } & \multicolumn{2}{|c|}{ Catalyst Containing } & \multirow[b]{2}{*}{ VOCs to Oxidize } \\
\hline & & $\begin{array}{c}\text { Au loading } \\
\text { (wt.\%)/Composition }\end{array}$ & Ce and: & \\
\hline Liu, 2021 & [145] & 1 &,$- \mathrm{Nb}$ & Benzene \\
\hline $\mathrm{Bu}, 2020$ & [146] & 1 & - & Formaldehyde \\
\hline Gaálová, 2019 & [144] & $0.20-3.35$ & $\mathrm{Zr}$ & Ethanol, Toluene \\
\hline Nevanpera, 2019 & [147] & $\mathrm{Pt}-\mathrm{Au}, \mathrm{Cu}-\mathrm{Au}$ &,$- \mathrm{Al}$ & Dimethyl disulfide \\
\hline Aboukaïs, 2016 & [148] & 4 & - & Propylene, Toluene \\
\hline Wang, 2015 & [149] & $0.91-1.11$ & Hydroxyapatite & Formaldehyde, Benzene \\
\hline Fiorenza, 2015 & [150] & $\mathrm{Au}-\mathrm{Ag}, \mathrm{Au}-\mathrm{Cu}$ & - & 2-propanol, Ethanol and Toluene \\
\hline Idakiev, 2015 & [151] & $1.36-3.21$ & $\mathrm{Ti}, \mathrm{Zr}$ & Methanol, Dimethylether \\
\hline Topka, 2015 & [138] & 0.3 and 2.8 & $\mathrm{Zr}$ & Chlorobenzene \\
\hline Barakat, 2014 & [152] & $2.36-2.99$ & $\mathrm{Ti}, \mathrm{Fe}, \mathrm{Ni}$ & Toluene \\
\hline Tabakova, 2013 & [153] & 3 & $\mathrm{Mn}, \mathrm{Fe}, \mathrm{Co}$ & Methanol \\
\hline Aboukaïs, 2013 & [140] & 0.5 and 4 & - & Propylene and toluene \\
\hline Mandal, 2013 & [154] & 3.5 & $\mathrm{Mn}$ & Benzyl alcohol \\
\hline Matějová, 2013 & [155] & 0.3 and 2.8 & $\mathrm{Zr}$ & Ethanol and dichloromethane \\
\hline Petrova, 2013 & {$[156]$} & 3 & Co & Benzene \\
\hline Ciftci, 2013 & [157] & $<0.01$ to 2.14 & - & Ethanol and formic acid \\
\hline Bastos, 2012 & [158] & 0.75 and 0.77 & (compared to Mn) & Ethyl acetate, ethanol and toluene \\
\hline Bazin, 2012 & [159] & 1 & - & Methanol \\
\hline Ilieva, 2012 & [160] & 3 & Co & Benzene \\
\hline Li, 2011 & [161] & $2.5-3$ & - & Formaldehyde \\
\hline Solsona, 2011 & [162] & 2.2 & $\mathrm{Ni}$ & Propane \\
\hline Gaálová, 2011 & [68] & 0.3 and 2.5 & $\mathrm{Zr}$ & Ethanol and toluene \\
\hline Tana, 2011 & [163] & 3.2 & - & Carbon monoxide \\
\hline Bonelli, 2011 & [164] & $1,2.2$ and 2.7 & $\mathrm{Fe}$ & Methanol and toluene \\
\hline Ousmane, 2011 & [165] & 1.1 & $\mathrm{Al}$ & Propene and toluene \\
\hline Ying, 2011 & [166] & 1.1 and 1.7 & - & Benzene \\
\hline Scirè, 2010 & [167] & $4.3-4.6$ & - & Methanol, Acetone, Toluene \\
\hline Lakshmanan, 2010 & [168] & 1 & $\mathrm{Al}$ & Propene \\
\hline Delannoy, 2010 & [169] & $0.25-4$ & - & Propene \\
\hline Rousseau, 2010 & [139] & 1 & - & Methanol \\
\hline Zhang, 2009 & [170] & $0.42-0.56$ & - & Formaldehyde \\
\hline Gennequin, 2009 & {$[171]$} & 2.64 & $\mathrm{Ti}, \mathrm{Zr}$ & Propene and toluene \\
\hline Shen, 2008 & [172] & $0-0.85$ & - & Formaldehyde \\
\hline Lamallem, 2008 & [173] & $1.5-3.3$ & $\mathrm{Ti}$ & Propene \\
\hline Jia, 2008 & {$[174]$} & 1 & - & Formaldehyde \\
\hline Gennequin, 2007 & [175] & $2.7-3.5$ & $\mathrm{Ti}$ & Propene \\
\hline Pina, 2006 & {$[176]$} & 1 & $\mathrm{Zr}$ & Benzene, hexane, chlorobenzene \\
\hline Andreeva, 2006 & [177] & $2.8,2.9$ and 3 & Mo, Al & Benzene \\
\hline Gluhoi, 2005 & [178] & 4.5 & $\begin{array}{c}\mathrm{Al} \text { (compared to } \mathrm{Co}, \mathrm{Mn}, \\
\mathrm{Fe})\end{array}$ & Propene \\
\hline Andreeva, 2004 & [179] & 2.3 and 3 & $\mathrm{~V}, \mathrm{Al}$ & Benzene \\
\hline Centeno, 2002 & [180] & 1.5 and 2.5 & $\mathrm{Al}$ & n-hexane, benzene and 2-propanol \\
\hline
\end{tabular}


Bonelli et al. [164] reported the design of nano-sized $\mathrm{Au} / \mathrm{FeO}_{\mathrm{x}}$ catalysts supported on $\mathrm{CeO}_{2}$ for total oxidation of methanol and toluene. The presence of iron in the $\mathrm{CeO}_{2}$ structure was found to increase Au dispersion by creating sites with an increased electronic density, which act in a similar way to oxygen vacancies. The deposition of gold nanoparticles was favored at these sites. A strong influence of the nature of dopant was observed by Tabakova et al. [181] as well. The same group evaluated the activity of different doped AuCe catalysts towards the oxidation of $\mathrm{CH}_{3} \mathrm{OH}$; the activity decreased in the order: $\mathrm{AuCeCo}>\mathrm{AuCe}>\mathrm{AuCeFe}>$ AuCeMn [153].

The different behaviour of noble metals $[152,163,167]$ offers the possibility of designing bimetallic catalysts. Lee and Chen reported on the mutual promotional effect of $\mathrm{Au}-\mathrm{Pd} / \mathrm{CeO}_{2}$ bimetallic catalysts on the destruction of toluene [182]. The addition of a suitable amount of gold to $\mathrm{Pd} / \mathrm{CeO}_{2}$ increased the proportion of metallic palladium and the catalytic activity.

\section{Cordierite Monolithic Catalysts for VOC Oxidation}

For practical applications, macro-structured catalysts are preferred over powdered catalysts. A low-pressure drop in the exhaust system, good thermal resistance, refractoriness, good washcoat adherence and compatibility between the washcoat and the catalyst are only a few excellent operational properties of cordierite monoliths, which are more than suitable for gas phase applications [183]. A catalytic layer can be deposited onto cordierite monolith by numerous techniques, selected accordingly to the VOCs to be oxidized. Similar to powder catalysts, the selectivity to carbon dioxide is important, as the by-products formed (Figure 6) may be more detrimental than the original VOC.

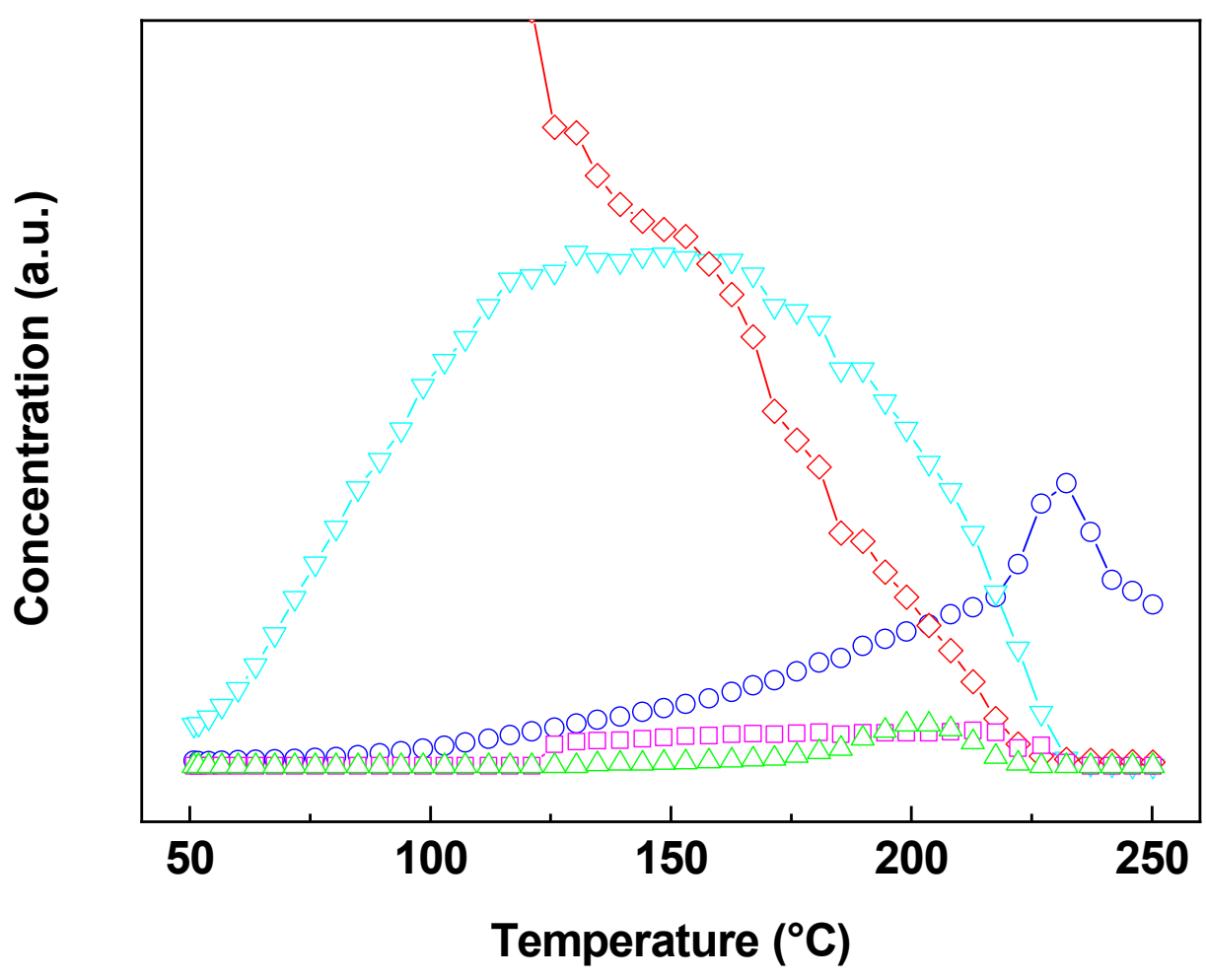

Figure 6. The evolution of by-products during ethanol oxidation over the powder $\mathrm{Au} / \mathrm{Ce}_{0.5} \mathrm{Zr}_{0.5} \mathrm{O}_{2}$ catalyst studied in Ref. [68]: ethanol (red), ethylene (blue), acetaldehyde (cyan), acetic acid (magenta) and ethyl acetate (green).

The catalytic combustion of toluene over Fe-Mn mixed oxides supported on cordierite monolith was investigated by Ma et al. [184]. The high dispersion of the mixed oxides on the surface of the cordierite support was the most important factor for the catalytic combustion of VOCs. Total oxidation of naphthalene at low temperatures using palladium nanoparticles 
supported on inorganic oxide-coated cordierite honeycomb monoliths was the subject of the research of Varela-Gandía et al. [28]. Thin films of ZSM-5 and BETA zeolites, and a SAPO-5 silicoaluminophosphate (by in situ synthesis), then $\gamma-\mathrm{Al}_{2} \mathrm{O}_{3}$ (by a dip-coating), were coated onto a cordierite honeycomb monolith. The coated monoliths were impregnated with polymer-protected Pd nanoparticles and tested for the total oxidation of naphthalene. From the combined use of the zeolite with polymer-protected nanoparticles, enhanced catalytic properties were found for the total abatement of the representative of VOCs. A high degree of stability remained even after undergoing accelerated ageing experiments.

Aguero et al. reported the catalytic combustion of different VOCs: ethyl acetate, n-hexane, and its mixture [185]. Cordierite monolith was dipped in colloidal alumina slurry, dried and calcined. After that, impregnation with aqueous solutions of $\left(\mathrm{CH}_{3} \mathrm{CO}_{2}\right)_{2} \mathrm{Mn} \times 4 \mathrm{H}_{2} \mathrm{O}$ and $\left(\mathrm{CH}_{3} \mathrm{CO}_{2}\right)_{2} \mathrm{Cu} \times 4 \mathrm{H}_{2} \mathrm{O}$, drying and calcination was carried out. Prepared $\mathrm{MnCu}$-mixed oxide catalysts with homogeneous and well-adhered coatings revealed very good activity and stability in the oxidation of VOCs.

Zhao et al. tested $\mathrm{Cu}_{x} \mathrm{Co}_{1-x} / \mathrm{Al}_{2} \mathrm{O}_{3} /$ cordierite monolithic catalysts $(\mathrm{x}=0-1)$ in the catalytic combustion of toluene [186]. A boehmite primer sol was the first washcoat layer, and copper with cobalt oxides was the activity washcoat layer. The $\mathrm{Cu}_{0.5} \mathrm{Co}_{0.5} / \mathrm{Al}_{2} \mathrm{O}_{3} /$ cordierite catalyst with $\mathrm{Co}^{2+}$ and $\mathrm{Co}^{3+}$ on its surface showed the best catalytic activity; toluene was completely oxidized at $315^{\circ} \mathrm{C}$.

Zhou et al. [187] studied $\mathrm{MnO}_{\mathrm{x}}-\mathrm{CeO}_{2} / \mathrm{La}-\mathrm{Al}_{2} \mathrm{O}_{3}$ monolithic catalysts prepared by the deposition-precipitation method, impregnation method and a combination of the two methods in toluene oxidation. The results showed that the catalyst prepared by the deposition-precipitation method showed the best catalytic activity and possessed richer surface oxygen species, a higher proportion of $\mathrm{Mn}^{4+}$ and good low-temperature redox properties.

From existing patents dealing with catalysts supported on ceramic monoliths with honeycomb structure for VOCs oxidation, the sequential adsorptive capture and catalytic oxidation defined in the US 6479022 B1 patent can be mentioned [188]. The inventors recommend grinding the active component to a powder with a particle size smaller than 20 microns, followed by a coating over the carrier such as cordierite. A method for the catalytic oxidation of $\mathrm{VOC} / \mathrm{CO}$ in the presence of organosilicate compounds describes the patent EP 0993857 B1 [189]. As an example of suitable ceramic materials, it states cordierite, preferred for the treatment of gases containing halogenated organics. Cordieritebased monolithic catalyst without coating layer is the key idea of the CN 102989451 A patent [190]. The acidification treatment and the coating technology of the selected carrier are not required; the load capacity of the metal active component is controllable; the metal active component has good stability. The invention mainly solves the problems of complicated processes and the high cost of the preparation of the existing cordierite monolithic catalyst.

\section{Au Monolithic Catalysts for VOC Oxidation}

Gold catalysts for indoor air quality control already appeared as prototype products in the public domain [191]. Air-cleaning devices are required for removing CO, VOCs and ozone from ambient air in confined spaces such as submarines or space crafts on long missions and indoor office space [192]. The gold/titanium dioxide photocatalytic/thermocatalytic coating (where gold particles have a size lower than $3 \mathrm{~nm}$ ) is used by Carrier Corporation (US) for the simultaneous oxidation of VOCs and carbon monoxide [193]. When photons of ultraviolet light are absorbed by $\mathrm{Au} / \mathrm{TiO}_{2}$ coating, reactive hydroxyl radicals are formed. They oxidize a contaminant, adsorbed on the coating, to $\mathrm{H}_{2} \mathrm{O}, \mathrm{CO}_{2}$ and other substances. Gold is an oxidation catalyst that lowers the barrier energy of $\mathrm{CO}$ to be oxidized to carbon dioxide. It is particularly gainful that the activity of Au catalysts may be promoted by moisture. Oxidation of VOCs was studied using an inlet from the electrophotographic printing apparatus vapor stream [194]. The invention detailed the technology linking an apparatus and method for the oxidation of VOCs from a 
printer, particularly a combination of an unsupported and a supported oxidation catalyst. A method of dividing the supported oxidation catalyst into sections to obtain efficient oxidation of VOCs is included in the patent. Gas from within the printer body is conducted to a catalytic treatment system with separate contact regions for an unsupported oxidation catalyst (metal selected from the platinum group metals or from the first transition series) and a supported oxidation catalyst on different ceramic materials. Since 1992, $\mathrm{Au} / \mathrm{Fe}_{2} \mathrm{O}_{3}$ supported on washcoated honeycomb has been used in Japanese toilets for the elimination of bad smells [195]. The commercial use of gold-based catalysts is rather limited for now, but this field is undergoing an exciting period of discovery" [196].

\section{7. $\mathrm{CeO}_{2}$-Based Cordierite Monolithic Catalysts for VOC Oxidation}

Ce oxides have been known for many years as active and selective catalysts for VOC oxidation due to their oxygen storage capacity (OSC), redox properties and catalytic performances. The rheological properties of the suspension that contains the active elements are critical for obtaining a satisfactory washcoating [197]. The viscosity, concentration or $\mathrm{pH}$ of the slurry influences the adhesion ability of oxides towards cordierite honeycombs [198]. Table 3 displays several examples of successful depositions of ceria (possibly with other compounds) on cordierite monolith for VOC oxidation.

Table 3. Recently studied ceria containing VOC oxidation catalysts supported on cordierite monoliths.

\begin{tabular}{|c|c|c|c|c|}
\hline \multirow[t]{2}{*}{ 1st Author, Publ. Year } & \multirow{2}{*}{ Ref. } & \multicolumn{2}{|c|}{$\begin{array}{c}\text { Catalyst Supported on Cordierite } \\
\text { Monolith Containing }\end{array}$} & \multirow[t]{2}{*}{ VOCs to Oxidize } \\
\hline & & Noble Metal & Ce and: & \\
\hline Sedjame, 2018 & [199] & $\mathrm{Pt}$ & $\mathrm{Al}, \mathrm{Zr}$, & Acetic acid \\
\hline Zhou, 2018 & [187] & - & $\mathrm{Mn}, \mathrm{La}, \mathrm{Al}$ & Toluene \\
\hline Azalim, 2013 & [197] & - & $\mathrm{Mn}, \mathrm{Zr}$ & N-butanol \\
\hline Huang, 2013 & [200] & - & $\mathrm{Mn}$ & Benzene \\
\hline Jiang, 2013 & [201] & $\mathrm{Pt}, \mathrm{Pd}$ & $\mathrm{Al}, \mathrm{Zr}$ & $\begin{array}{c}\text { Toluene, benzene and } \\
\text { styrene }\end{array}$ \\
\hline Papavasiliou, 2009 & [202] & $\mathrm{Pt}$ & $\mathrm{Al}, \mathrm{Zr}, \mathrm{La}$ & Propene \\
\hline Liotta, 2009 & [203] & $\mathrm{Pt}$ & $\mathrm{Al}, \mathrm{Zr}$ & Propene \\
\hline Zhi Min, 2007 & [134] & $\mathrm{Pt}$ & $\mathrm{Al}, \mathrm{Zr}, \mathrm{Mn}, \mathrm{Y}$ & Toluene \\
\hline González-Velasco, 2002 & [204] & $\mathrm{Pt}$ & $\mathrm{Zr}$ & Propene \\
\hline Agrafiotis, 2001 & [205] & $\mathrm{Pd}, \mathrm{Rh}$ & $\mathrm{Al}, \mathrm{Ca}$ & $\begin{array}{l}\text { Exhaust gases } \\
\text { (hydrocarbons) }\end{array}$ \\
\hline
\end{tabular}

Agrafiotis et al. [205] evaluated nanophase calcia-doped-ceria-based washcoats deposited on ceramic honeycombs (via sol-gel methods) with respect to catalytic activity for hydrocarbons conversion and thermal aging. The activity of the systems was found to depend strongly on the deposition method (directly from the sol or from suspensions of sol-gel derived powders), on the type of precursor used for preparing the starting sols (metallo-organic or inorganic) and on the method used to insert the noble metal(s) in/on the washcoat.

González-Velasco et al. studied $0.58 \mathrm{Pt} / \mathrm{Ce}_{0.68} \mathrm{Zr}_{0.32} \mathrm{O}_{2} /$ ceramic monolith for simultaneous elimination of $\mathrm{NO}, \mathrm{C}_{3} \mathrm{H}_{6}$ and $\mathrm{CO}$ [204]. Changes in activity have been related to the role of platinum and ceria-zirconia mixed oxide in the reaction milieu; the authors claim the advantages of using ceria-zirconia mixed oxides instead of $\mathrm{CeO}_{2} / \mathrm{Al}_{2} \mathrm{O}_{3}$ to improve stability and oxygen storage capacity. Zhi Min et al. [134] demonstrated that the catalytic activity of $\mathrm{Pt} / \gamma-\mathrm{Al}_{2} \mathrm{O}_{3} / \mathrm{Ce}_{0.50} \mathrm{Zr}_{0.50} \mathrm{O}_{2}$ monolithic catalyst could be greatly improved by doping $\mathrm{Y}$ and $\mathrm{Mn}$ into $\mathrm{Ce}_{0.50} \mathrm{Zr}_{0.50} \mathrm{O}_{2}$. 
Remarkable stabilization of the ceria-zirconia solution towards $\mathrm{CeAlO}_{3}$ formation operated by Pt under redox conditions managed to achieved Liotta et al. [203] by preparation of structured $1 \mathrm{Pt} / \mathrm{CeZr} / \mathrm{Al}$ catalyst, dip-coated over a cordierite monolithic support. $\mathrm{Pt}$ supported catalysts ceria-zirconia was present as a $\mathrm{Ce}_{0.6} \mathrm{Zr}_{0.4} \mathrm{O}_{2}$ homogeneous solid solution, and the deposition over the cordierite does not produce any structural modification; moreover, no Pt sintering occurred.

Among the preparation procedures for $\mathrm{Ce}-\mathrm{Zr}-\mathrm{La}$ modified $\mathrm{Pt} / \gamma-\mathrm{Al}_{2} \mathrm{O}_{3}$ catalyst(i) simultaneous coprecipitation of $\gamma$-alumina and ceria-based solid solution from metal nitrates, (ii) sequential coprecipitation of these components and (iii) wet impregnation with different $\gamma$-alumina powders-simultaneous coprecipitation led to the most thermally stable washcoat [202]. Papavasiliou et al. observed higher dispersion of the oxide modifiers in the alumina carrier, impeding the Pt sintering.

The monolithic Pt-Pd bimetallic catalysts supported on $\gamma-\mathrm{Al}_{2} \mathrm{O}_{3}$ using cordierite honeycomb ceramics as the first carrier were prepared by thermal adsorption method by Jiang et al. [201]. The Pt-Pd content of $0.1 \%$ was found to be suitable; the prepared catalyst shows high activity and stability. On the contrary, cerium-based catalyst supported on cordierite with no noble metal was used for catalytic combustion of benzene by Huang et al. [200]. Their results specified that the $\mathrm{MnCeO}_{x} /$ Cord catalyst with Mn/Ce molar ratio of 1:1, calcined for $7 \mathrm{~h}$ and $\mathrm{M}^{n+} /$ (citric acid) molar ratio of 6 exhibited the highest catalytic activity. Recently, the direct deposition of Ce-Zr-Mn mixed oxide on the cordierite has been proposed as an alternative and promising way to the alumina-coated cordierite followed by noble metal impregnation for VOCs catalytic removal by Azalim et al. [197]. The retaining of the great textural and the redox properties of the $\mathrm{Ce}_{0.12} \mathrm{Zr}_{0.40} \mathrm{Mn}_{0.48} \mathrm{O}_{2}$ mixed oxides, already observed on the powder catalyst, was most likely the main reason for the excellent catalytic properties of the CeZrMn(0.48)/M monolith.

Several cordierite monolithic catalysts with ceria washcoat for VOC abatement were patented as well. An instance can be the US-8475755-B2 patent [206], which includes platinum group metals, one of which is either platinum or ruthenium.

\section{8. $\mathrm{Au} / \mathrm{CeO}_{2}$ Cordierite Monolithic Catalysts for VOC Oxidation}

Gold and ceria supported on a cordierite monolith are employed in several published patents. The US-7329359-B2 patent describes the use of Ce-Zr mixed oxides, together with a promoter from the transition metal oxides group, coated on a ceramic cordierite monolith for the destruction of VOCs in liquid media [207]. Exhaust gas (including VOCs) treatment catalyst is proposed in the WO 2013088091 A1 patent [208]. A catalytic system consisting of an oxide (preferably of fluorite crystalline structure) corresponds to the molar formula: $\mathrm{Ce}_{1-\mathrm{u}} \mathrm{M}_{\mathrm{y}} \mathrm{A}_{\mathrm{z}} \mathrm{D}_{\mathrm{v}} \mathrm{O}_{2-\mathrm{x}}$, where $\mathrm{Ce}$ is cerium, $\mathrm{A}$ represents at least one element having several degrees of oxidation, $M$ represents at least one element chosen from Gd, Y, Se, Sm, Nd, Pr and $\mathrm{Zn}, \mathrm{D}$ represents at least one element different from $\mathrm{A}$ and chosen from $\mathrm{Pt}, \mathrm{Pd}, \mathrm{Rh}, \mathrm{Ru}$, $\mathrm{Cu}, \mathrm{Fe}, \mathrm{Ag}$ and $\mathrm{Au}, \mathrm{u}$ is between 0.05 and 0.45 , $\mathrm{y}$ is between 0.01 and $0.4, \mathrm{z}$ is greater than 0 and less than $0.4, \mathrm{v}$ is between 0.001 and 0.4 and $\mathrm{x}$ is greater than 0 . The VOC oxidation catalysts based on $\mathrm{Ce}-\mathrm{Zr}$ mixed oxides, noble metals, and promoters are proposed in other patents [209,210]. For adequate exposure of the catalysts to the contaminated air stream, without producing excessive back pressure, the catalyst is deposited on structured support. Another catalyst compositions useful for destruction of VOCs in an oxygen-containing gas stream at low temperatures (the patent WO 2001045833 A1 [211]) comprises one or more first metals selected from the group consisting of: Ce and Zr; and at least one of: (a) one or more second metals selected from the group consisting of: $\mathrm{Gd}, \mathrm{La}, \mathrm{Sr}$ and Sc; (b) one or more third metals selected from the group consisting of: $\mathrm{Ti}, \mathrm{V}, \mathrm{Mn}, \mathrm{Fe}, \mathrm{Co}, \mathrm{Cr}, \mathrm{Ni}, \mathrm{Au}$, $\mathrm{Ag}$ and $\mathrm{Cu}$; and (c) one or more fourth metals selected from the group consisting of $\mathrm{Pt}, \mathrm{Pd}$, $\mathrm{Rh}, \mathrm{Ru}, \mathrm{Re}, \mathrm{Os}$ and Ir. Catalyst compositions provided may be single-phase, mixed-metal oxides, or multi-phase. 
Monoliths coated with perovskites and ion exchange materials are described as highly efficient catalytic materials for VOCs abatement in the following patents: US 5882616 A [212] and US 6200483 B1 [213].

The method of coating a honeycomb monolith substrate with a catalyst component is proposed in the WO 2011080525 A1 patent [214]. Ceria is recommended as one of the suitable coatings for supporting the catalytically active metals, preferably from the following group: $\mathrm{Pt}, \mathrm{Pd}, \mathrm{Au}, \mathrm{Ag}$, Ir, $\mathrm{Ru}, \mathrm{Rh}$ and Os. Methods of preparing highly dispersed monolithic gold catalysts are described in the WO2011106213 patent [215]. Nanosized gold catalysts are supported on the washcoated monoliths, stabilized by the addition of a third metal oxide, which may include a variety of transition metal oxides such as cerium oxide. The introduction of monolithic supported Au catalysts potentially can be beneficial for environmental catalyses, such as the low-temperature oxidation of VOCs and CO.

Recently, we proposed two methods of gold introduction during the preparation of $\mathrm{Au} / \mathrm{Ce}_{0.5} \mathrm{Zr}_{0.5} \mathrm{O}_{2}$ cordierite monolithic catalysts [137]. We have demonstrated that the order of gold and ceria introduction may influence gold particle size and thus the catalytic activity. The enhanced reducibility of the catalysts with higher Au dispersion led to an improved catalytic performance in ethanol oxidation.

\section{Perspective}

Except for further improvement of the preparation methods aimed to obtain required gold particle size and particle size distribution, the effect of gold nanoparticles on ceria or ceria-zirconia support and its catalytic activity would deserve further studies. For example, it is generally accepted that the optimal gold particle size is in the range of nanometers. However, we have shown that in the oxidation of chlorobenzene, even large gold particle agglomerates $(\sim 100 \mathrm{~nm})$ may contribute to the catalytic performance of the $\mathrm{Au} / \mathrm{Ce}_{0.5} \mathrm{Zr}_{0.5} \mathrm{O}_{2}$ catalysts (cf. Figure 3) [138]. Furthermore, the role of the $\mathrm{Au}-\mathrm{CeO}_{2}$ interface is important and not yet fully understood. Depending on the type of VOC to be oxidized, the perimeter of Au nanoparticles may form the active site for the reaction. For example, for ethanol oxidation, it was reported that the presence of highly dispersed $\mathrm{Au}$ nanoparticles induced a new oxidation pathway [216]. Another interesting point might be the effect of ceria morphology (nanorods, nanocubes). It was already shown that the morphology of ceria might affect the interaction of the support with gold nanoparticles and thus the catalytic activity. For example, Bu et al. recently reported that ceria nanorods with exposed (110) and (100) planes possessed a large number of oxygen vacancies and promoted the creation of $\mathrm{Au}^{3+}$ near the surface [146].

\section{Conclusions}

Gold and ceria are well-known catalysts that already proved their performance in the total oxidation of VOCs. While ceria itself may be highly active, its ability to oxidize given VOC can be improved by depositing gold nanoparticles. Furthermore, gold nanoparticles can improve the selectivity of catalysts. This is crucial, as the oxidation by-products may be more detrimental than the original VOC. Choosing the proper preparation method is crucial to obtain catalysts that are able to totally oxidize VOCs at low temperatures and avoiding deactivation. Gold nanoparticles deposited on the partly reducible ceria is an especially suitable combination due to the oxygen storage/release capacity of such catalysts. The decisive role of oxygen vacancies and their mobility was confirmed in many studies. On the other hand, the catalytic activity and selectivity of gold/ceria catalysts may be substantially influenced by the nature of the VOC to be oxidized.

The kinetic behavior of the supported catalysts is usually affected mainly by their reducibility, acidobasic properties, morphology, and oxidation state of the active phase. The number and mobility of surface vacancies and lattice oxygens-involved in VOC oxidation through a Mars-van Krevelen reaction mechanism-is a key issue. The activity of the gold/ceria catalysts is influenced by gold particle size. It was revealed that the small particle size of gold, $\sim 5 \mathrm{~nm}$, has a positive effect on the catalyst performance; such $\mathrm{Au} / \mathrm{CeO}_{2}$ 
systems are preferably prepared by deposition-precipitation. New approaches, such as plasma deposition, allow to obtain the narrow size distribution of gold nanoparticles and achieve a better understanding of the effects of gold particle size. Attention should be paid to a proper determination of the gold particle size, especially when using an electron microscope; HAADF-STEM is preferable to distinguish gold nanoparticles on the ceria surface and should be confirmed by EDX. The limiting factors of the oxidation process using $\mathrm{Au} / \mathrm{CeO}_{2}$ based powder catalysts are poisoning phenomena (ceria is sensitive to halogen and sulfur-containing compounds), thermal stability (to prevent both gold and ceria agglomeration) and mass and heat transfer limitations.

Catalytic technology at an industrial scale uses mainly monolithic washcoated catalysts with precious metals $(\mathrm{Pt}, \mathrm{Pd}, \mathrm{Rh})$ supported on oxygen storage components, such as ceria or ceria-zirconia mixed oxides. The application of monolithic catalysts to VOC removal is a crucial issue for practical applications in order to minimize the pressure drop in the reactor, allowing treatment of high flow rates frequently used in environmental applications. The factors influencing the activity of $\mathrm{Au} / \mathrm{CeO}_{2}$ based washcoats are similar to powder catalysts. However, the method used to introduce the gold in/on the washcoat (e.g., washcoating powder $\mathrm{Au} / \mathrm{CeO}_{2}$ catalyst or introducing gold to already washcoated $\mathrm{CeO}_{2}$ ) may influence the gold particle size and thus the activity of the catalyst.

Author Contributions: J.G.: investigation, supervision, and original draft; P.T.: methodology, formal analysis, review and editing. Both authors have read and agreed to the published version of the manuscript.

Funding: This research was funded by the Technology Agency of the Czech Republic, project number TN01000048, and by the Czech Science Foundation, grant number 19-08153Y.

Conflicts of Interest: The authors declare no conflict of interest.

\section{References}

1. Ojala, S.; Pitkaaho, S.; Laitinen, T.; Koivikko, N.N.; Brahmi, R.; Gaalova, J.; Matejova, L.; Kucherov, A.; Paivarinta, S.; Hirschmann, C.; et al. Catalysis in VOC Abatement. Top. Catal. 2011, 54, 1224-1256. [CrossRef]

2. Costagliola, M.A.; Murena, F.; Prati, M.V. Exhaust emissions of volatile organic compounds of powered two-wheelers: Effect of cold start and vehicle speed. Contribution to greenhouse effect and tropospheric ozone formation. Sci. Total Environ. 2014, 468-469, 1043-1049. [CrossRef]

3. Spivey, J.J. Complete Catalytic-Oxidation of Volatile Organics. Ind. Eng. Chem. Res. 1987, 26, 2165-2180. [CrossRef]

4. Tichenor, B.A.; Palazzolo, M.A. Destruction of volatile organic compounds via catalytic incineration. Environ. Prog. 1987, 6, 172-176. [CrossRef]

5. Spivey, J.J.; Butt, J.B. Literature review: Deactivation of catalysts in the oxidation of volatile organic compounds. Catal. Today 1992, 11, 465-500. [CrossRef]

6. Busca, G.; Finocchio, E.; Lorenzelli, V.; Ramis, G.; Baldi, M. IR studies on the activation of C-H hydrocarbon bonds on oxidation catalysts. Catal. Today 1999, 49, 453-465. [CrossRef]

7. Rymeš, J.; Ehret, G.; Hilaire, L.; Boutonnet, M.; Jirátová, K. Microemulsions in the preparation of highly active combustion catalysts. Catal. Today 2002, 75, 297-303. [CrossRef]

8. Windawi, H.; Zhang, Z.C. Catalytic destruction of halogenated air toxins and the effect of admixture with VOCs. Catal. Today 1996, 30, 99-105. [CrossRef]

9. Vu, V.H.; Belkouch, J.; Ould-Dris, A.; Taouk, B. Catalytic oxidation of volatile organic compounds on manganese and copper oxides supported on titania. AIChE J. 2008, 54, 1585-1591. [CrossRef]

10. Hayes, R.E.; Kolackowski, S.T. Introduction to Catalytic Combustion; OPA: Amsterdam, The Netherlands, 1997.

11. Moretti, E.C. Practical Solutions for Reducing Volatile Organic Compounds and Hazardous Air Pollutants; AIChE: New York, NY, USA, 2001.

12. Bahranowski, K.; Dula, R.; Gąsior, M.; Łabanowska, M.; Michalik, A.; Vartikian, L.A.; Serwicka, E.M. Oxidatoin of aromatic hydrocarbons with hydrogen peroxide over Zn,Cu,Al-layered double hydroxides. Appl. Clay Sci. 2001, 18, 93-101. [CrossRef]

13. Bielański, A.; Najbar, M. $\mathrm{V}_{2} \mathrm{O}_{5}-\mathrm{MoO}_{3}$ catalysts for benzene oxidation. Appl. Catal. A Gen. 1997, 157, 223-261. [CrossRef]

14. Sahle-Demessie, E.; Devulapelli, V.G. Vapor phase oxidation of dimethyl sulfide with ozone over $\mathrm{V}_{2} \mathrm{O}_{5} / \mathrm{TiO}_{2}$ catalyst. Appl. Catal. B Environ. 2008, 84, 408-419. [CrossRef]

15. Lamonier, J.-F.; Boutoundou, A.-B.; Gennequin, C.; Pérez-Zurita, M.; Siffert, S.; Aboukais, A. Catalytic Removal of Toluene in Air over Co-Mn-Al Nano-oxides Synthesized by Hydrotalcite Route. Catal. Lett. 2007, 118, 165-172. [CrossRef]

16. Jirátová, K.; Mikulová, J.; Klempa, J.; Grygar, T.; Bastl, Z.; Kovanda, F. Modification of Co-Mn-Al mixed oxide with potassium and its effect on deep oxidation of VOC. Appl. Catal. A Gen. 2009, 361, 106-116. [CrossRef] 
17. Liotta, L.F. Catalytic oxidation of volatile organic compounds on supported noble metals. Appl. Catal. B Environ. 2010, 100, 403-412. [CrossRef]

18. Heck, R.M.; Farrauto, R.J.; Gulati, S.T. Catalytic Air Pollution Control, 2nd ed.; John Wiley \& Sons Inc.: New York, NY, USA, 2002.

19. Papaefthimiou, P.; Ioannides, T.; Verykios, X.E. Combustion of non-halogenated volatile organic compounds over group VIII metal catalysts. Appl. Catal. B Environ. 1997, 13, 175-184. [CrossRef]

20. Marecot, P.; Fakche, A.; Kellali, B.; Mabilon, G.; Prigent, M.; Barbier, J. Propane and Propene Oxidation over Platinum and Palladium on Alumina-Effects of Chloride and Water. Appl. Catal. B Environ. 1994, 3, 283-294. [CrossRef]

21. Patterson, M.J.; Angove, D.E.; Cant, N.W. The effect of carbon monoxide on the oxidation of four C6 to C8 hydrocarbons over platinum, palladium and rhodium. Appl. Catal. B 2000, 26, 47-57. [CrossRef]

22. Paulis, M.; Gandía, L.M.; Gil, A.; Sambeth, J.; Odriozola, J.A.; Montes, M. Influence of the surface adsorption-desorption processes on the ignition curves of volatile organic compounds (VOCs) complete oxidation over supported catalysts. Appl. Catal. B Environ. 2000, 26, 37-46. [CrossRef]

23. Maillet, T.; Solleau, C.; Barbier, J., Jr.; Duprez, D. Oxidation of carbon monoxide, propene, propane and methane over a $\mathrm{Pd} / \mathrm{Al}_{2} \mathrm{O}_{3}$ catalyst. Effect of the chemical state of Pd. Appl. Catal. B Environ. 1997, 14, 85-95. [CrossRef]

24. Wu, J.C.S.; Lin, Z.-A.; Pan, J.-W.; Rei, M.-H. A novel boron nitride supported Pt catalyst for VOC incineration. Appl. Catal. A Gen. 2001, 219, 117-124. [CrossRef]

25. Ferrandon, M.; Björnbom, E. Hydrothermal Stabilization by Lanthanum of Mixed Metal Oxides and Noble Metal Catalysts for Volatile Organic Compound Removal. J. Catal. 2001, 200, 148-159. [CrossRef]

26. van den Brink, R.W.; Louw, R.; Mulder, P. Formation of polychlorinated benzenes during the catalytic combustion of chlorobenzene using a Pt $/ \gamma-\mathrm{Al}_{2} \mathrm{O}_{3}$ catalyst. Appl. Catal. B 1998, 16, 219-226. [CrossRef]

27. Okumura, K.; Kobayashi, T.; Tanaka, H.; Niwa, M. Toluene combustion over palladium supported on various metal oxide supports. Appl. Catal. B Environ. 2003, 44, 325-331. [CrossRef]

28. Varela-Gandia, F.J.; Berenguer-Murcia, A.; Lozano-Castello, D.; Cazorla-Amoros, D.; Sellick, D.R.; Taylor, S.H. Total oxidation of naphthalene at low temperatures using palladium nanoparticles supported on inorganic oxide-coated cordierite honeycomb monoliths. Catal. Sci. Technol. 2013, 3, 2708-2716. [CrossRef]

29. Huang, S.; Zhang, C.; He, H. Effect of pretreatment on $\mathrm{Pd} / \mathrm{Al}_{2} \mathrm{O}_{3}$ catalyst for catalytic oxidation of o-xylene at low temperature. J. Environ. Sci. 2013, 25, 1206-1212. [CrossRef]

30. Pitkäaho, S.; Nevanperä, T.; Matejova, L.; Ojala, S.; Keiski, R.L. Oxidation of dichloromethane over Pt, Pd, Rh, and V2O5 catalysts supported on $\mathrm{Al}_{2} \mathrm{O}_{3}, \mathrm{Al}_{2} \mathrm{O}_{3}-\mathrm{TiO}_{2}$ and $\mathrm{Al}_{2} \mathrm{O}_{3}-\mathrm{CeO}_{2}$. Appl. Catal. B Environ. 2013, 138-139, 33-42. [CrossRef]

31. Hammer, B.; Norskov, J.K. Why gold is the noblest of all the metals. Nature 1995, 376, 238-240. [CrossRef]

32. Price, C.A.H.; Pastor-Pérez, L.; Ivanova, S.; Reina, T.R.; Liu, J. The Success Story of Gold-Based Catalysts for Gas- and Liquid-Phase Reactions: A Brief Perspective and Beyond. Front. Chem. 2019, 7, 691. [CrossRef]

33. Chen, X.; Zhu, H. 3.01-Catalysis by Supported Gold Nanoparticles. In Comprehensive Nanoscience and Technology; David, L.A., Gregory, D.S., Gary, P.W., Eds.; Academic Press: Amsterdam, The Netherlands, 2011; pp. 1-11.

34. Liu, Y.; Dai, H.; Deng, J.; Li, X.; Wang, Y.; Arandiyan, H.; Xie, S.; Yang, H.; Guo, G. Au/3DOM La ${ }_{0.6} \mathrm{Sr}_{0.4} \mathrm{MnO}_{3}$ : Highly active nanocatalysts for the oxidation of carbon monoxide and toluene. J. Catal. 2013, 305, 146-153. [CrossRef]

35. Guan, Y.; Hensen, E.J.M. Ethanol dehydrogenation by gold catalysts: The effect of the gold particle size and the presence of oxygen. Appl. Catal. A Gen. 2009, 361, 49-56. [CrossRef]

36. Ojeda, M.; Iglesia, E. Formic Acid Dehydrogenation on Au-Based Catalysts at Near-Ambient Temperatures. Angezw. Chem. Int. Ed. 2009, 48, 4800-4803. [CrossRef] [PubMed]

37. Bulushev, D.A.; Beloshapkin, S.; Ross, J.R.H. Hydrogen from formic acid decomposition over Pd and Au catalysts. Catal. Today 2010, 154, 7-12. [CrossRef]

38. Gazsi, A.; Bánsági, T.; Solymosi, F. Decomposition and Reforming of Formic Acid on Supported Au Catalysts: Production of CO-Free $\mathrm{H}_{2}$. J. Phys. Chem. C 2011, 115, 15459-15466. [CrossRef]

39. Albonetti, S.; Bonelli, R.; Mengou, J.E.; Femoni, C.; Tiozzo, C.; Zacchini, S.; Trifiro, F. Gold/iron carbonyl clusters as precursors for $\mathrm{TiO}_{2}$ supported catalysts. Catal. Today 2008, 137, 483-488. [CrossRef]

40. Albonetti, S.; Bonelli, R.; Delaigle, R.; Femoni, C.; Gaigneaux, E.M.; Morandi, V.; Ortolani, L.; Tiozzo, C.; Zacchini, S.; Trifiro, F. Catalytic combustion of toluene over cluster-derived gold/iron catalysts. Appl. Catal. A Gen. 2010, 372, 138-146. [CrossRef]

41. Bonelli, R.; Lucarelli, C.; Pasini, T.; Liotta, L.F.; Zacchini, S.; Albonetti, S. Total oxidation of volatile organic compounds on $\mathrm{Au} / \mathrm{FeOx}$ catalysts supported on mesoporous SBA-15 silica. Appl. Catal. A Gen 2011, 400, 54-60. [CrossRef]

42. Haruta, M.; Ueda, A.; Tsubota, S.; Sanchez, R.M.T. Low-temperature catalytic combustion of methanol and its decomposed derivatives over supported gold catalysts. Catal. Today 1996, 29, 443-447. [CrossRef]

43. Minico, S.; Scire, S.; Crisafulli, C.; Maggiore, R.; Galvagno, S. Catalytic combustion of volatile organic compounds on gold/iron oxide catalysts. Appl. Catal. B Environ. 2000, 28, 245-251. [CrossRef]

44. Minico, S.; Scire, S.; Crisafulli, C.; Galvagno, S. Influence of catalyst pretreatments on volatile organic compounds oxidation over gold/iron oxide. Appl. Catal. B Environ. 2001, 34, 277-285. [CrossRef] 
45. Albonetti, S.; Bonelli, R.; Delaigle, R.; Gaigneaux, E.M.; Femoni, C.; Riccobene, P.M.; Scirè, S.; Tiozzo, C.; Zacchini, S.; Trifirò, F. Design of nano-sized FeOx and $\mathrm{Au} / \mathrm{FeOx}$ catalysts for total oxidation of VOC and preferential oxidation of CO. In Studies in Surface Science and Catalysis; Gaigneaux, E.M., Devillers, M., Hermans, S., Jacobs, P.A., Martens, J.A., Ruiz, P., Eds.; Elsevier: Amsterdam, The Netherlands, 2010; pp. 785-788.

46. Yuan, Y.; Asakura, K.; Wan, H.; Tsai, K.; Iwasawa, Y. Preparation of supported gold catalysts from gold complexes and their catalytic activities for CO oxidation. Catal. Lett. 1996, 42, 15-20. [CrossRef]

47. Ramírez-Garza, R.E.; Pawelec, B.; Zepeda, T.A.; Martínez-Hernández, A. Total CO oxidation over Fe-containing Au/HMS catalysts: Effects of gold loading and catalyst pretreatment. Catal. Today 2011, 172, 95-102. [CrossRef]

48. Santos, V.P.; Carabineiro, S.A.C.; Tavares, P.B.; Pereira, M.F.R.; Orfao, J.J.M.; Figueiredo, J.L. Oxidation of CO, ethanol and toluene over $\mathrm{TiO}_{2}$ supported noble metal catalysts. Appl. Catal. B Environ. 2010, 99, 198-205. [CrossRef]

49. Zhang, C.; He, H. A comparative study of $\mathrm{TiO}_{2}$ supported noble metal catalysts for the oxidation of formaldehyde at room temperature. Catal. Today 2007, 126, 345-350. [CrossRef]

50. Ruth, K.; Hayes, M.; Burch, R.; Tsubota, S.; Haruta, M. The effects of $\mathrm{SO}_{2}$ on the oxidation of $\mathrm{CO}$ and propane on supported Pt and Au catalysts. Appl. Catal. B Environ. 2000, 24, L133-L138. [CrossRef]

51. Hosseini, M.; Siffert, S.; Tidahy, H.L.; Cousin, R.; Lamonier, J.F.; Aboukais, A.; Vantomme, A.; Roussel, M.; Su, B.L. Promotional effect of gold added to palladium supported on a new mesoporous $\mathrm{TiO}_{2}$ for total oxidation of volatile organic compounds. Catal. Today 2007, 122, 391-396. [CrossRef]

52. Hosseini, M.; Siffert, S.; Cousin, R.; Aboukais, A.; Hadj-Sadok, Z.; Su, B.L. Total oxidation of VOCs on Pd and/or Au supported on $\mathrm{TiO}_{2} / \mathrm{ZrO}_{2}$ followed by “operando" DRIFT. C. R. Chim. 2009, 12, 654-659. [CrossRef]

53. Hosseini, M.; Barakat, T.; Cousin, R.; Aboukaïs, A.; Su, B.L.; de Weireld, G.; Siffert, S. Catalytic performance of core-shell and alloy Pd-Au nanoparticles for total oxidation of VOC: The effect of metal deposition. Appl. Catal. B Environ. 2012, 111-112, 218-224. [CrossRef]

54. Chen, M.S.; Goodman, D.W. Structure-activity relationships in supported Au catalysts. Catal. Today 2006, 111, 22-33. [CrossRef]

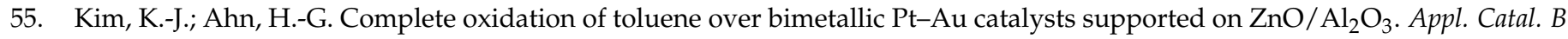
Environ. 2009, 91, 308-318. [CrossRef]

56. Wu, H.; Wang, L.; Shen, Z.; Zhao, J. Catalytic oxidation of toluene and p-xylene using gold supported on $\mathrm{Co}_{3} \mathrm{O}_{4} \mathrm{Catalyst}$ prepared by colloidal precipitation method. J. Mol. Catal. A Chem. 2011, 351, 188-195. [CrossRef]

57. Liu, S.Y.; Yang, S.M. Complete oxidation of 2-propanol over gold-based catalysts supported on metal oxides. Appl. Catal. A Gen. 2008, 334, 92-99. [CrossRef]

58. Andreeva, D.; Tabakova, T.; Idakiev, V.; Naydenov, A. Complete oxidation of benzene over $\mathrm{Au}-\mathrm{V}_{2} \mathrm{O}_{5} / \mathrm{TiO}_{2}$ and $\mathrm{Au}-\mathrm{V}_{2} \mathrm{O}_{5} / \mathrm{ZrO}_{2}$ Catalysts. Gold Bull. 1998, 31, 105-106. [CrossRef]

59. Idakiev, V.; Ilieva, L.; Andreeva, D.; Blin, J.L.; Gigot, L.; Su, B.L. Complete benzene oxidation over gold-vanadia catalysts supported on nanostructured mesoporous titania and zirconia. Appl. Catal. A Gen. 2003, 243, 25-39. [CrossRef]

60. Yang, S.M.; Liu, D.M.; Liu, S.Y. Catalytic combustion of benzene over Au supported on ceria and vanadia promoted ceria. Top. Catal. 2008, 47, 101-108. [CrossRef]

61. Ye, Q.; Zhao, J.; Huo, F.; Wang, D.; Cheng, S.; Kang, T.; Dai, H. Nanosized Au supported on three-dimensionally ordered mesoporous $\beta-\mathrm{MnO}_{2}$ : Highly active catalysts for the low-temperature oxidation of carbon monoxide, benzene, and toluene Microporous Mesoporous Mater. 2013, 172, 20-29. [CrossRef]

62. Cellier, C.; Lambert, S.; Gaigneaux, E.M.; Poleunis, C.; Ruaux, V.; Eloy, P.; Lahousse, C.; Bertrand, P.; Pirard, J.P.; Grange, P. Investigation of the preparation and activity of gold catalysts in the total oxidation of n-hexane. Appl. Catal. B Environ. 2007, 70, 406-416. [CrossRef]

63. Li, X.; Dai, H.; Deng, J.; Liu, Y.; Xie, S.; Zhao, Z.; Wang, Y.; Guo, G.; Arandiyan, H. Au/3DOM LaCoO 3 : High-performance catalysts for the oxidation of carbon monoxide and toluene. Chem. Eng. J. 2013, 228, 965-975. [CrossRef]

64. Solsona, B.; García, T.; Hutchings, G.J.; Taylor, S.H.; Makkee, M. TAP reactor study of the deep oxidation of propane using cobalt oxide and gold-containing cobalt oxide catalysts. Appl. Catal. A Gen. 2009, 365, 222-230. [CrossRef]

65. Miao, S.J.; Deng, Y.Q. Au-Pt/ $\mathrm{Co}_{3} \mathrm{O}_{4}$ catalyst for methane combustion. Appl. Catal. B Environ. 2001, 31, L1-L4. [CrossRef]

66. Solsona, B.; Garcia, T.; Agouram, S.; Hutchings, G.J.; Taylor, S.H. The effect of gold addition on the catalytic performance of copper manganese oxide catalysts for the total oxidation of propane. Appl. Catal. B Environ. 2011, 101, 388-396. [CrossRef]

67. Scirè, S.; Liotta, L.F. Supported gold catalysts for the total oxidation of volatile organic compounds. Appl. Catal. B 2012, 125, 222-246. [CrossRef]

68. Gaálová, J.; Topka, P.; Kaluža, L.; Šolcová, O. Gold versus platinum on ceria-zirconia mixed oxides in oxidation of ethanol and toluene. Catal. Today 2011, 175, 231-237. [CrossRef]

69. Oliver-Meseguer, J.; Cabrero-Antonino, J.R.; Domínguez, I.; Leyva-Pérez, A.; Corma, A. Small Gold Clusters Formed in Solution Give Reaction Turnover Numbers of 107 at Room Temperature. Science 2012, 338, 1452-1455. [CrossRef] [PubMed]

70. Gates, B.C. Supported gold catalysts: New properties offered by nanometer and sub-nanometer structures. Chem. Commun. 2013, 49, 7876-7877. [CrossRef] [PubMed]

71. Nevanpera, T.K.; Pitkaaho, S.; Ojala, S.; Keiski, R.L. Oxidation of Dichloromethane over Au, Pt, and Pt-Au Containing Catalysts Supported on gamma- $\mathrm{Al}_{2} \mathrm{O}_{3}$ and $\mathrm{CeO}_{2}-\mathrm{Al}_{2} \mathrm{O}_{3}$. Molecules 2020, 25, 4644. [CrossRef] [PubMed]

72. Nascimento, A. Theoretical Aspects of Heterogeneous Catalysis; Kluwer Academic Publishers: Dordrecht, The Netherlands, 2001. 
73. Kim, K.-J.; Boo, S.-I.; Ahn, H.-G. Preparation and characterization of the bimetallic Pt-Au/ $\mathrm{ZnO} / \mathrm{Al}_{2} \mathrm{O}_{3}$ catalysts: Influence of $\mathrm{Pt}-\mathrm{Au}$ molar ratio on the catalytic activity for toluene oxidation. J. Ind. Eng. Chem. 2009, 15, 92-97. [CrossRef]

74. Kim, K.; Kim, K.L.; Shin, K.S. Effect of organic vapors on Au, Ag, and Au-Ag alloy nanoparticle films with adsorbed 2,6dimethylphenyl isocyanide. J. Colloid Interface Sci. 2013, 411, 194-197. [CrossRef] [PubMed]

75. Barakat, T.; Rooke, J.C.; Tidahy, H.L.; Hosseini, M.; Cousin, R.; Lamonier, J.-F.; Giraudon, J.-M.; De Weireld, G.; Su, B.-L.; Siffert, S. Noble-Metal-Based Catalysts Supported on Zeolites and Macro-Mesoporous Metal Oxide Supports for the Total Oxidation of Volatile Organic Compounds. ChemSusChem 2011, 4, 1420-1430. [CrossRef]

76. Kan, C.; Cai, W.; Li, C.; Zhang, L.; Hofmeister, H. Ultrasonic synthesis and optical properties of Au/Pd bimetallic nanoparticles in ethylene glycol. J. Phys. D Appl. Phys. 2003, 36, 1609. [CrossRef]

77. Marx, S.; Baiker, A. Beneficial Interaction of Gold and Palladium in Bimetallic Catalysts for the Selective Oxidation of Benzyl Alcohol. J. Phys. Chem. C 2009, 113, 6191-6201. [CrossRef]

78. He, L.; Yu, Y.; Zhang, C.; He, H. Complete catalytic oxidation of o-xylene over $\mathrm{CeO}_{2}$ nanocubes. J. Environ. Sci. 2011, $23,160-165$. [CrossRef]

79. Puertolas, B.; Solsona, B.; Agouram, S.; Murillo, R.; Mastral, A.M.; Aranda, A.; Taylor, S.H.; Garcia, T. The catalytic performance of mesoporous cerium oxides prepared through a nanocasting route for the total oxidation of naphthalene. Appl. Catal. B Environ. 2010, 93, 395-405. [CrossRef]

80. Aranda, A.; Agouram, S.; López, J.M.; Mastral, A.M.; Sellick, D.R.; Solsona, B.; Taylor, S.H.; García, T. Oxygen defects: The key parameter controlling the activity and selectivity of mesoporous copper-doped ceria for the total oxidation of naphthalene. Appl. Catal. B Environ. 2012, 127, 77-88. [CrossRef]

81. Ozawa, M.; Yuzuriha, H.; Haneda, M. Total oxidation of toluene and oxygen storage capacity of zirconia-sol modified ceria zirconia. Catal. Commun. 2013, 30, 32-35. [CrossRef]

82. Gutiérrez-Ortiz, J.I.; de Rivas, B.; López-Fonseca, R.; González-Velasco, J.R. Combustion of aliphatic C2 chlorohydrocarbons over ceria-zirconia mixed oxides catalysts. Appl. Catal. A 2004, 269, 147-155. [CrossRef]

83. Sedjame, H.-J.; Fontaine, C.; Lafaye, G.; Barbier, J., Jr. On the promoting effect of the addition of ceria to platinum based alumina catalysts for VOCs oxidation. Appl. Catal. B 2014, 144, 233-242. [CrossRef]

84. Pitkäaho, S.; Matejova, L.; Ojala, S.; Gaalova, J.; Keiski, R.L. Oxidation of perchloroethylene-Activity and selectivity of Pt, Pd, Rh, and $\mathrm{V}_{2} \mathrm{O}_{5}$ catalysts supported on $\mathrm{Al}_{2} \mathrm{O}_{3}, \mathrm{Al}_{2} \mathrm{O}_{3}-\mathrm{TiO}_{2}$ and $\mathrm{Al}_{2} \mathrm{O}_{3}-\mathrm{CeO}_{2}$. Appl. Catal. B Environ. 2012, 113-114, 150-159. [CrossRef]

85. Zheng, J.; Wang, Z.; Chen, Z.; Zuo, S. Mechanism of $\mathrm{CeO}_{2}$ synthesized by thermal decomposition of Ce-MOF and its performance of benzene catalytic combustion. J. Rare Earths 2021, 39, 790-796. [CrossRef]

86. Zeng, Y.; Haw, K.-G.; Wang, Z.; Wang, Y.; Zhang, S.; Hongmanorom, P.; Zhong, Q.; Kawi, S. Double redox process to synthesize $\mathrm{CuO}-\mathrm{CeO}_{2}$ catalysts with strong $\mathrm{Cu}-\mathrm{Ce}$ interaction for efficient toluene oxidation. J. Hazard. Mater. 2021, 404, 124088. [CrossRef]

87. Jiang, Z.Y.; Jing, M.Z.; Feng, X.B.; Xiong, J.C.; He, C.; Douthwaite, M.; Zheng, L.R.; Song, W.Y.; Liu, J.; Qu, Z.G. Stabilizing platinum atoms on $\mathrm{CeO}_{2}$ oxygen vacancies by metal-support interaction induced interface distortion: Mechanism and application. Appl. Catal. B 2020, 278, 119304. [CrossRef]

88. Li, Y.X.; Han, W.; Wang, R.X.; Weng, L.T.; Serrano-Lotina, A.; Banares, M.A.; Wang, Q.Y.; Yeung, K.L. Performance of an aliovalent-substituted CoCeOx catalyst from bimetallic MOF for VOC oxidation in air. Appl. Catal. B 2020, 275, 119121. [CrossRef]

89. Sophiana, I.C.; Topandi, A.; Iskandar, F.; Devianto, H.; Nishiyama, N.; Budhi, Y.W. Catalytic oxidation of benzene at low temperature over novel combination of metal oxide based catalysts: $\mathrm{CuO}, \mathrm{MnO}_{2}, \mathrm{NiO}$ with $\mathrm{Ce}_{0.75} \mathrm{Zr}_{0.25} \mathrm{O}_{2}$ as support. Mater. Today Chem. 2020, 17. [CrossRef]

90. Al-Aani, H.M.S.; Trandafir, M.M.; Fechete, I.; Leonat, L.N.; Badea, M.; Negrila, C.; Popescu, I.; Florea, M.; Marcu, I.C. Highly Active Transition Metal-Promoted CuCeMgAlO Mixed Oxide Catalysts Obtained from Multicationic LDH Precursors for the Total Oxidation of Methane. Catalysts 2020, 10, 613. [CrossRef]

91. Figueredo, M.J.M.; Andana, T.; Bensaid, S.; Dosa, M.; Fino, D.; Russo, N.; Piumetti, M. Cerium-Copper-Manganese Oxides Synthesized via Solution Combustion Synthesis (SCS) for Total Oxidation of VOCs. Catal. Lett. 2020, 150, 1821-1840. [CrossRef]

92. Jiang, C.L.; Wang, H.; Wang, Y.Q.; Xue, C.; Yang, Z.J.; Yu, C.L.; Ji, H.B. Modifying defect States in CeO 2 by Fe doping: A strategy for low-temperature catalytic oxidation of toluene with sunlight. J. Hazard. Mater. 2020, 390, 122182. [CrossRef]

93. Zheng, Y.; Zhao, Q.; Shan, C.; Lu, S.; Su, Y.; Han, R.; Song, C.; Ji, N.; Ma, D.; Liu, Q. Enhanced Acetone Oxidation over the $\mathrm{CeO}_{2} / \mathrm{Co}_{3} \mathrm{O}_{4}$ Catalyst Derived from Metal-Organic Frameworks. ACS Appl. Mater. Interfaces 2020, 12, 28139-28147. [CrossRef]

94. Jiang, Y.W.; Gao, J.H.; Zhang, Q.; Liu, Z.Y.; Fu, M.L.; Wu, J.L.; Hu, Y.; Ye, D.Q. Enhanced oxygen vacancies to improve ethyl acetate oxidation over $\mathrm{MnOx}-\mathrm{CeO}_{2}$ catalyst derived from MOF template. Chem. Eng. J. 2019, 371, 78-87. [CrossRef]

95. Wang, Q.Y.; Li, Z.M.; Banares, M.A.; Weng, L.T.; Gu, Q.F.; Price, J.; Han, W.; Yeung, K.L. A Novel Approach to High-Performance Aliovalent-Substituted Catalysts-2D Bimetallic MOF-Derived $\mathrm{CeCuO}_{\mathrm{x}}$ Microsheets. Small 2019, 15. [CrossRef]

96. Genty, E.; Siffert, S.; Cousin, R. Investigation of reaction mechanism and kinetic modelling for the toluene total oxidation in presence of CoAlCe catalyst. Catal. Today 2019, 333, 28-35. [CrossRef]

97. Shah, P.M.; Burnett, J.W.H.; Morgan, D.J.; Davies, T.E.; Taylor, S.H. Ceria-Zirconia Mixed Metal Oxides Prepared via Mechanochemical Grinding of Carbonates for the Total Oxidation of Propane and Naphthalene. Catalysts 2019, 9, 475. [CrossRef]

98. Chen, Z.; Li, J.; Yang, P.; Cheng, Z.; Li, J.R.; Zuo, S.F. Ce-modified mesoporous gamma- $\mathrm{Al}_{2} \mathrm{O}_{3}$ supported Pd-Pt nanoparticle catalysts and their structure-function relationship in complete benzene oxidation. Chem. Eng. J. 2019, 356, 255-261. [CrossRef] 
99. Gołąbek, K.; Palomares, A.E.; Martínez-Triguero, J.; Tarach, K.A.; Kruczała, K.; Girman, V.; Góra-Marek, K. Ce-modified zeolite BEA catalysts for the trichloroethylene oxidation. The role of the different and necessary active sites. Appl. Catal. B 2019, 259, 118022. [CrossRef]

100. Okal, J.; Zawadzki, M.; Kraszkiewicz, P.; Adamska, K. Ru/ $\mathrm{CeO}_{2}$ catalysts for combustion of mixture of light hydrocarbons: Effect of preparation method and metal salt precursors. Appl. Catal. A 2018, 549, 161-169. [CrossRef]

101. Hosseini, M.; Haghighi, M.; Kahforoushan, D.; Zarrabi, M. Sono-dispersion of ceria and palladium in preparation and characterization of $\mathrm{Pd} / \mathrm{Al}_{2} \mathrm{O}_{3}$-clinoptilolite- $\mathrm{CeO}_{2}$ nanocatalyst for treatment of polluted air via low temperature VOC oxidation. Process. Saf. Environ. Protect. 2017, 106, 284-293. [CrossRef]

102. Konsolakis, M.; Carabineiro, S.A.C.; Marnellos, G.E.; Asad, M.F.; Soares, O.; Pereira, M.F.R.; Orfao, J.J.M.; Figueiredo, J.L. Effect of cobalt loading on the solid state properties and ethyl acetate oxidation performance of cobalt-cerium mixed oxides. J. Colloid Interface Sci. 2017, 496, 141-149. [CrossRef]

103. Piumetti, M.; Bensaid, S.; Andana, T.; Russo, N.; Pirone, R.; Fino, D. Cerium-copper oxides prepared by solution combustion synthesis for total oxidation reactions: From powder catalysts to structured reactors. Appl. Catal. B 2017, 205, 455-468. [CrossRef]

104. Saedy, S.; Haghighi, M.; Fatehifar, E.; Abbasi, Z. Effect of ceria content on physicochemical and catalytic properties of nanostructured $\mathrm{CeO}_{2} / \mathrm{Al}_{2} \mathrm{O}_{3}$ used for catalytic removal of toluene from waste gas streams. Environ. Eng. Manag. J. 2017, 16, 251-259.

105. Issa, G.S.; Dimitrov, M.D.; Kovacheva, D.G.; Henych, J.; Stengl, V.; Tsoncheva, T.S. Effect of phase composition on the formation of active sites in titania-ceria catalysts for ethyl acetate total oxidation. Bulg. Chem. Commun. 2017, 49, 114-120.

106. He, D.D.; Chen, D.K.; Hao, H.S.; Yu, J.; Liu, J.P.; Lu, J.C.; Liu, F.; Wan, G.P.; He, S.F.; Luo, Y.M. Structural/surface characterization and catalytic evaluation of rare-earth (Y, Sm and La) doped ceria composite oxides for $\mathrm{CH}_{3} \mathrm{SH}$ catalytic decomposition. Appl. Surf. Sci. 2016, 390, 959-967. [CrossRef]

107. Carabineiro, S.A.C.; Konsolakis, M.; Marnellos, G.E.N.; Asad, M.F.; Soares, O.; Tavares, P.B.; Pereira, M.F.R.; Orfao, J.J.D.; Figueiredo, J.L. Ethyl Acetate Abatement on Copper Catalysts Supported on Ceria Doped with Rare Earth Oxides. Molecules 2016, 21, 644. [CrossRef] [PubMed]

108. Topka, P.; Kaluža, L.; Gaálová, J. Total oxidation of ethanol and toluene over ceria-zirconia supported platinum catalysts. Chem. Pap. 2016, 70, 898-906. [CrossRef]

109. Dinh, M.T.N.; Giraudon, J.M.; Vandenbroucke, A.M.; Morent, R.; de Geyter, N.; Lamonier, J.F. Post plasma-catalysis for total oxidation of trichloroethylene over Ce-Mn based oxides synthesized by a modified "redox-precipitation route". Appl. Catal. B 2015, 172, 65-72. [CrossRef]

110. Abdelouahab-Reddam, Z.; el Mail, R.; Coloma, F.A. Sepulveda-Escribano, Effect of the metal precursor on the properties of $\mathrm{Pt} / \mathrm{CeO}_{2} / \mathrm{C}$ catalysts for the total oxidation of ethanol. Catal. Today 2015, 249, 109-116. [CrossRef]

111. Xue, B.; Guo, H.M.; Liu, L.J.; Chen, M. Preparation, characterization and catalytic properties of yttrium-zirconium-pillared montmorillonite and their application in supported Ce catalysts. Clay Min. 2015, 50, 211-219. [CrossRef]

112. Yosefi, L.; Haghighi, M.; Allahyari, S.; Ashkriz, S. The beneficial use of HCl-activated natural zeolite in ultrasound assisted synthesis of $\mathrm{Cu}$ /clinoptilolite- $\mathrm{CeO}_{2}$ nanocatalyst used for catalytic oxidation of diluted toluene in air at low temperature. J. Chem. Technol. Biotechnol. 2015, 90, 765-774. [CrossRef]

113. Nousir, S.; Maache, R.; Azalim, S.; Agnaou, M.; Brahmi, R.; Bensitel, M. Synthesis and investigation of the physico-chemical properties of catalysts based on mixed oxides CexZr $r_{1-x} \mathrm{O}_{2}$. Arab. J. Chem. 2015, 8, 222-227. [CrossRef]

114. Yang, P.; Meng, Z.H.; Yang, S.S.; Shi, Z.N.; Zhou, R.X. Highly active behaviors of $\mathrm{CeO}_{2}-\mathrm{CrOx}$ mixed oxide catalysts in deep oxidation of 1,2-dichloroethane. J. Mol. Catal. A Chem. 2014, 393, 75-83. [CrossRef]

115. Deng, Q.F.; Ren, T.Z.; Agula, B.; Liu, Y.P.; Yuan, Z.Y. Mesoporous $\mathrm{Ce}_{x} \mathrm{Zr}_{1-x} \mathrm{O}_{2}$ solid solutions supported CuO nanocatalysts for toluene total oxidation. J. Ind. Eng. Chem. 2014, 20, 3303-3312. [CrossRef]

116. Perez, A.; Molina, R.; Moreno, S. Enhanced VOC oxidation over Ce/CoMgAl mixed oxides using a reconstruction method with EDTA precursors. Appl. Catal. A 2014, 477, 109-116. [CrossRef]

117. Urbutis, A.; Kitrys, S. Dual function adsorbent-catalyst $\mathrm{CuO}-\mathrm{CeO}_{2} / \mathrm{NaX}$ for temperature swing oxidation of benzene, toluene and xylene. Cent. Eur. J. Chem. 2014, 12, 492-501. [CrossRef]

118. Konsolakis, M.; Carabineiro, S.A.C.; Tavares, P.B.; Figueiredo, J.L. Redox properties and VOC oxidation activity of Cu catalysts

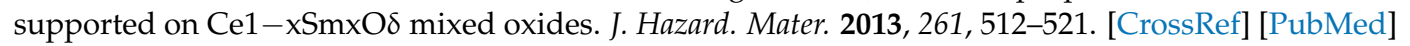

119. Yue, L.; He, C.; Zhang, X.; Li, P.; Wang, Z.; Wang, H.; Hao, Z. Catalytic behavior and reaction routes of MEK oxidation over Pd/ZSM-5 and Pd-Ce/ZSM-5 catalysts. J. Hazard. Mater. 2013, 244-245, 613-620. [CrossRef] [PubMed]

120. Dziembaj, R.; Molenda, M.; Zaitz, M.M.; Chmielarz, L.; Furczon, K. Correlation of electrical properties of nanometric copperdoped ceria materials $\left(\mathrm{Ce}_{1-x} \mathrm{Cu}_{\mathrm{x}} \mathrm{O}_{2}\right.$-delta) with their catalytic activity in incineration of VOCs. Solid State Ion. 2013, 251, 18-22. [CrossRef]

121. Shi, C.; Chen, B.-B.; Li, X.-S.; Crocker, M.; Wang, Y.; Zhu, A.-M. Catalytic formaldehyde removal by "storage-oxidation" cycling process over supported silver catalysts. Chem. Eng. J. 2012, 200-202, 729-737. [CrossRef]

122. Matějová, L.; Topka, P.; Jirátová, K.; Šolcová, O. Total oxidation of model volatile organic compounds over some commercial catalysts. Appl. Catal. A 2012, 443, 40-49. [CrossRef]

123. Abbasi, Z.; Haghighi, M.; Fatehifar, E.; Saedy, S. Synthesis and physicochemical characterizations of nanostructured $\mathrm{Pt} / \mathrm{Al}_{2} \mathrm{O}_{3}-$ $\mathrm{CeO}_{2}$ catalysts for total oxidation of VOCs. J. Hazard. Mater. 2011, 186, 1445-1454. [CrossRef] 
124. Pérez, A.; Montes, M.; Molina, R.; Moreno, S. Cooperative effect of Ce and Pr in the catalytic combustion of ethanol in mixed $\mathrm{Cu} / \mathrm{CoMgAl}$ oxides obtained from hydrotalcites. Appl. Catal. A Gen. 2011, 408, 96-104. [CrossRef]

125. Weng, X.; Zhang, J.; Wu, Z.; Liu, Y. Continuous hydrothermal flow syntheses of transition metal oxide doped Ce $\mathrm{TiO}_{2}$ nanopowders for catalytic oxidation of toluene. Catal. Today 2011, 175, 386-392. [CrossRef]

126. Mayernick, A.D.; Janik, M.J. Methane oxidation on Pd-Ceria: A DFT study of the mechanism over PdxCe $\mathrm{P}_{1-\mathrm{x}} \mathrm{O}_{2}, \mathrm{Pd}$, and PdO. J. Catal. 2011, 278, 16-25. [CrossRef]

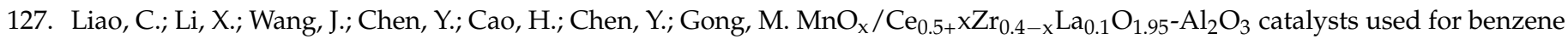
catalytic combustion. J. Rare Earths 2011, 29, 109-113. [CrossRef]

128. Yu, D.; Liu, Y.; Wu, Z. Low-temperature catalytic oxidation of toluene over mesoporous $\mathrm{MnO}_{\mathrm{x}}-\mathrm{CeO}_{2} / \mathrm{TiO}_{2}$ prepared by sol-gel method. Catal. Commun. 2010, 11, 788-791. [CrossRef]

129. Masui, T.; Imadzu, H.; Matsuyama, N.; Imanaka, N. Total oxidation of toluene on $\mathrm{Pt} / \mathrm{CeO}_{2}-\mathrm{ZrO}_{2}-\mathrm{Bi}_{2} \mathrm{O}_{3} / \gamma-\mathrm{Al}_{2} \mathrm{O}_{3}$ catalysts prepared in the presence of polyvinyl pyrrolidone. J. Hazard. Mater. 2010, 176, 1106-1109. [CrossRef]

130. Ferreira, A.C.; Ferraria, A.M.; Rego, A.M.B.d.; Gonçalves, A.P.; Girão, A.V.; Correia, R.; Gasche, T.A.; Branco, J.B. Partial oxidation of methane over bimetallic copper-cerium oxide catalysts. J. Mol. Catal. A Chem. 2010, 320, 47-55. [CrossRef]

131. Azalim, S.; Brahmi, R.; Bensitel, M.; Giraudon, J.-M.; Lamonier, J.-F. Preparation and characterization of nanocrystallines Mn-CeZr mixed oxide catalysts by sol-gel method: Application to the complete oxidation of n-butanol. In Studies in Surface Science and Catalysis; Gaigneaux, E.M., Ruiz, P., Eds.; Elsevier: Amsterdam, The Netherlands, 2010; pp. 731-734.

132. Delimaris, D.; Ioannides, T. VOC oxidation over $\mathrm{MnO}_{\mathrm{x}}-\mathrm{CeO}_{2}$ catalysts prepared by a combustion method. Appl. Catal. B Environ. 2008, 84, 303-312. [CrossRef]

133. Yan, S.; Wang, J.; Zhong, J.; Chen, Y.; Liu, Z.; Cao, H.; Gong, M. Effect of metal doping into $\mathrm{Ce}_{0.5} \mathrm{Zr}_{0.5} \mathrm{O}_{2}$ on catalytic activity of $\mathrm{MnO}_{\mathrm{x}} / \mathrm{Ce}_{0.5-\mathrm{x}} \mathrm{Zr}_{0.5-\mathrm{x}} \mathrm{M}_{0.2 \mathrm{x}} \mathrm{O}_{\mathrm{y}} / \mathrm{Al}_{2} \mathrm{O}_{3}$ for benzene combustion. J. Rare Earths 2008, 26, 841-845. [CrossRef]

134. Min, L.Z.; Li, W.J.; Bo, Z.J.; Qiang, C.Y.; Hui, Y.S.; Chu, G.M. Catalytic combustion of toluene over platinum supported on Ce-Zr-O solid solution modified by Y and Mn. J. Hazard. Mater. 2007, 149, 742-746. [CrossRef]

135. Scirè, S.; Minicò, S.; Crisafulli, C.; Satriano, C.; Pistone, A. Catalytic combustion of volatile organic compounds on gold/cerium oxide catalysts. Appl. Catal. B Environ. 2003, 40, 43-49. [CrossRef]

136. Li, J.; Li, W. Effect of preparation method on the catalytic activity of $\mathrm{Au} / \mathrm{CeO}_{2}$ for VOCs oxidation. J. Rare Earths 2010, $28,547-551$. [CrossRef]

137. Topka, P.; Klementová, M. Total oxidation of ethanol over $\mathrm{Au} / \mathrm{Ce}_{0.5} \mathrm{Zr}_{0.5} \mathrm{O}_{2}$ cordierite monolithic catalysts. Appl. Catal. A 2016, 522, 130-137. [CrossRef]

138. Topka, P.; Delaigle, R.; Kaluža, L.; Gaigneaux, E.M. Performance of platinum and gold catalysts supported on ceria-zirconia mixed oxide in the oxidation of chlorobenzene. Catal. Today 2015, 253, 172-177. [CrossRef]

139. Rousseau, S.; Marie, O.; Bazin, P.; Daturi, M.; Verdier, S.; Harlé, V. Investigation of methanol oxidation over Au/catalysts using operando IR spectroscopy: Determination of the active sites, intermediate/spectator species, and reaction mechanism. J. Am. Chem. Soc. 2010, 132, 10832-10841. [CrossRef]

140. Aboukaïs, A.; Aouad, S.; El-Ayadi, H.; Skaf, M.; Labaki, M.; Cousin, R.; Abi-Aad, E. Catalytic Oxidation of Propylene, Toluene, Carbon Monoxide, and Carbon Black over $\mathrm{Au} / \mathrm{CeO}_{2}$ Solids: Comparing the Impregnation and the Deposition-Precipitation Methods. Sci. World J. 2013, 2013, 824979. [CrossRef]

141. Takei, T.; Akita, T.; Nakamura, I.; Fujitani, T.; Okumura, M.; Okazaki, K.; Huang, J.; Ishida, T.; Haruta, M. Chapter OneHeterogeneous Catalysis by Gold. In Advances in Catalysis; Bruce, C.G., Friederike, C.J., Eds.; Academic Press: New York, NY, USA, 2012; pp. 1-126.

142. Prati, L.; Villa, A. The Art of Manufacturing Gold Catalysts. Catalysts 2011, 2, 24-37. [CrossRef]

143. Fujitani, T.; Nakamura, I. Mechanism and Active Sites of the Oxidation of $\mathrm{CO}$ over $\mathrm{Au} / \mathrm{TiO}_{2}$. Angew. Chem. Int. Ed. 2011, 50, 10144-10147. [CrossRef]

144. Gaálová, J.; Topka, P.; Kaluža, L.; Soukup, K.; Barbier, J. Effect of gold loading on ceria-zirconia support in total oxidation of VOCs. Catal. Today 2019, 333, 190-195. [CrossRef]

145. Liu, Z.; Zhang, X.; Cai, T.; Yuan, J.; Zhao, K.; Lu, W.; He, D. Niobium Modification of Au/CeO 2 for Enhanced Catalytic Performance over Benzene Combustion. Nanomaterials 2021, 11, 189. [CrossRef]

146. Bu, Y.; Chen, Y.; Jiang, G.; Hou, X.; Li, S.; Zhang, Z. Understanding of Au-CeO interface and its role in catalytic oxidation of formaldehyde. Appl. Catal. B 2020, 260, 118138. [CrossRef]

147. Nevanpera, T.K.; Ojala, S.; Laitinen, T.; Pitkaaho, S.; Saukko, S.; Keiski, R.L. Catalytic Oxidation of Dimethyl Disulfide over Bimetallic $\mathrm{Cu}-\mathrm{Au}$ and Pt-Au Catalysts Supported on gamma- $\mathrm{Al}_{2} \mathrm{O}_{3}, \mathrm{CeO}_{2}$, and $\mathrm{CeO}_{2}-\mathrm{Al}_{2} \mathrm{O}_{3}$. Catalysts 2019, 9, 603. [CrossRef]

148. Aboukaïs, A.; Skaf, M.; Hany, S.; Cousin, R.; Aouad, S.; Labaki, M.; Abi-Aad, E. A comparative study of Cu, Ag and Au doped $\mathrm{CeO}_{2}$ in the total oxidation of volatile organic compounds (VOCs). Mater. Chem. Phys. 2016, 177, 570-576. [CrossRef]

149. Wang, Y.; Chen, B.B.; Crocker, M.; Zhang, Y.J.; Zhu, X.B.; Shi, C. Understanding on the origins of hydroxyapatite stabilized gold nanoparticles as high-efficiency catalysts for formaldehyde and benzene oxidation. Catal. Comm. 2015, 59, 195-200. [CrossRef]

150. Fiorenza, R.; Crisafulli, C.; Condorelli, G.G.; Lupo, F.; Scire, S. Au-Ag/ $\mathrm{CeO}_{2}$ and $\mathrm{Au}-\mathrm{Cu} / \mathrm{CeO} 2$ Catalysts for Volatile Organic Compounds Oxidation and CO Preferential Oxidation. Catal. Lett. 2015, 145, 1691-1702. [CrossRef] 
151. Idakiev, V.; Dimitrov, D.; Tabakova, T.; Ivanov, K.; Yuan, Z.Y.; Su, B.L. Catalytic abatement of CO and volatile organic compounds in waste gases by gold catalysts supported on ceria-modified mesoporous titania and zirconia. Chin. J. Catal. 2015, 36, 579-587. [CrossRef]

152. Barakat, T.; Idakiev, V.; Cousin, R.; Shao, G.S.; Yuan, Z.Y.; Tabakova, T.; Siffert, S. Total oxidation of toluene over noble metal based Ce, Fe and Ni doped titanium oxides. Appl. Catal. B Environ. 2014, 146, 138-146. [CrossRef]

153. Tabakova, T.; Dimitrov, D.; Manzoli, M.; Vindigni, F.; Petrova, P.; Ilieva, L.; Zanella, R.; Ivanov, K. Impact of metal doping on the activity of $\mathrm{Au} / \mathrm{CeO}_{2}$ catalysts for catalytic abatement of VOCs and CO in waste gases. Catal. Commun. 2013, 35, 51-58. [CrossRef]

154. Mandal, S.; Santra, C.; Bando, K.K.; James, O.O.; Maity, S.; Mehta, D.; Chowdhury, B. Aerobic oxidation of benzyl alcohol over mesoporous Mn-doped ceria supportedAu nanoparticle catalyst. J. Mol. Catal. A Chem. 2013, 378, 47. [CrossRef]

155. Matějová, L.; Topka, P.; Kaluža, L.; Pitkäaho, S.; Ojala, S.; Gaálová, J.; Keiski, R.L. Total oxidation of dichloromethane and ethanol over ceria-zirconia mixed oxide supported platinum and gold catalysts. Appl. Catal. B Environ. 2013, 142-143, 54-64. [CrossRef]

156. Petrova, P.; Tabakova, T.; Munteanu, G.; Zanella, R.; Tsvetkov, M.; Ilieva, L. Gold catalysts on Co-doped ceria for complete benzene oxidation: Relationship between reducibility and catalytic activity. Catal. Commun. 2013, 36, 84-88. [CrossRef]

157. Ciftci, A.; Ligthart, D.A.J.M.; Pastorino, P.; Hensen, E.J.M. Nanostructured ceria supported Pt and Au catalysts for the reactions of ethanol and formic acid. Appl. Catal. B Environ. 2013, 130-131, 325-335. [CrossRef]

158. Bastos, S.S.T.; Carabineiro, S.A.C.; Órfão, J.J.M.; Pereira, M.F.R.; Delgado, J.J.; Figueiredo, J.L. Total oxidation of ethyl acetate, ethanol and toluene catalyzed by exotemplated manganese and cerium oxides loaded with gold. Catal. Today 2012, 180, 148-154 [CrossRef]

159. Bazin, P.; Thomas, S.; Marie, O.; Daturi, M. New insights into the methanol oxidation mechanism over $\mathrm{Au} / \mathrm{CeO} 2$ catalyst through complementary kinetic and FTIR operando SSITKA approaches. Catal. Today 2012, 182, 3-11. [CrossRef]

160. Ilieva, L.; Petrova, P.; Tabakova, T.; Zanella, R.; Abrashev, M.V.; Sobczak, J.W.; Lisowski, W.; Kaszkur, Z.; Andreeva, D. Relationship between structural properties and activity in complete benzene oxidation over $\mathrm{Au} / \mathrm{CeO}_{2}-\mathrm{CoO}_{\mathrm{x}}$ catalysts. Catal. Today 2012, 187, 30-38. [CrossRef]

161. Li, H.-F.; Zhang, N.; Chen, P.; Luo, M.-F.; Lu, J.-Q. High surface area $\mathrm{Au} / \mathrm{CeO}_{2}$ catalysts for low temperature formaldehyde oxidation. Appl. Catal. B Environ. 2011, 110, 279-285. [CrossRef]

162. Solsona, B.; Garcia, T.; Aylón, E.; Dejoz, A.M.; Vázquez, I.; Agouram, S.; Davies, T.E.; Taylor, S.H. Promoting the activity and selectivity of high surface area Ni-Ce-O mixed oxides by gold deposition for VOC catalytic combustion. Chem. Eng. J. 2011, 175, 271-278. [CrossRef]

163. Wang, F.; Li, H.; Shen, W. Influence of Au particle size on $\mathrm{Au} / \mathrm{CeO}_{2}$ catalysts for $\mathrm{CO}$ oxidation. Catal. Today 2011, $175,541-545$.

164. Bonelli, R.; Albonetti, S.; Morandi, V.; Ortolani, L.; Riccobene, P.M.; Scirè, S.; Zacchini, S. Design of nano-sized FeOx and Au/FeOx catalysts supported on $\mathrm{CeO}_{2}$ for total oxidation of VOC. Appl. Catal. A Gen. 2011, 395, 10-18. [CrossRef]

165. Ousmane, M.; Liotta, L.F.; Carlo, G.D.; Pantaleo, G.; Venezia, A.M.; Deganello, G.; Retailleau, L.; Boreave, A.A. Giroir-Fendler, Supported Au catalysts for low-temperature abatement of propene and toluene, as model VOCs: Support effect. Appl. Catal. B Environ. 2011, 101, 629-637. [CrossRef]

166. Ying, F.; Wang, S.; Au, C.-T.; Lai, S.-Y. Highly active and stable mesoporous $\mathrm{Au} / \mathrm{CeO}_{2}$ catalysts prepared from $\mathrm{MCM}-48$ hard-template. Microporous Mesoporous Mater. 2011, 142, 308-315. [CrossRef]

167. Scirè, S.; Riccobene, P.M.; Crisafulli, C. Ceria supported group IB metal catalysts for the combustion of volatile organic compounds and the preferential oxidation of CO. Appl. Catal. B 2010, 101, 109-117. [CrossRef]

168. Lakshmanan, P.; Delannoy, L.; Richard, V.; Méthivier, C.; Potvin, C.; Louis, C. Total oxidation of propene over $\mathrm{Au} / \mathrm{xCeO}_{2}-\mathrm{Al}_{2} \mathrm{O}_{3}$ catalysts: Influence of the $\mathrm{CeO}_{2}$ loading and the activation treatment. Appl. Catal. B Environ. 2010, 96, 117-125. [CrossRef]

169. Delannoy, L.; Fajerwerg, K.; Lakshmanan, P.; Potvin, C.; Méthivier, C.; Louis, C. Supported gold catalysts for the decomposition of VOC: Total oxidation of propene in low concentration as model reaction. Appl. Catal. B Environ. 2010, 94, 117-124. [CrossRef]

170. Zhang, J.; Jin, Y.; Li, C.; Shen, Y.; Han, L.; Hu, Z.; Di, X.; Liu, Z. Creation of three-dimensionally ordered macroporous Au/CeO 2 catalysts with controlled pore sizes and their enhanced catalytic performance for formaldehyde oxidation. Appl. Catal. B Environ. 2009, 91, 11-20. [CrossRef]

171. Gennequin, C.; Lamallem, M.; Cousin, R.; Siffert, S.; Idakiev, V.; Tabakova, T.; Aboukaïs, A.; Su, B.L. Total oxidation of volatile organic compounds on $\mathrm{Au} / \mathrm{Ce}-\mathrm{Ti}-\mathrm{O}$ and $\mathrm{Au} / \mathrm{Ce}-\mathrm{Ti}-\mathrm{Zr}-\mathrm{O}$ mesoporous catalysts. J. Mater. Sci. 2009, 44, 6654-6662. [CrossRef]

172. Shen, Y.; Yang, X.; Wang, Y.; Zhang, Y.; Zhu, H.; Gao, L.; Jia, M. The states of gold species in $\mathrm{CeO}_{2}$ supported gold catalyst for formaldehyde oxidation. Appl. Catal. B Environ. 2008, 79, 142-148. [CrossRef]

173. Lamallem, M.; Ayadi, H.E.; Gennequin, C.; Cousin, R.; Siffert, S.; Aïssi, F.; Aboukaïs, A. Effect of the preparation method on $\mathrm{Au} / \mathrm{Ce}-\mathrm{Ti}-\mathrm{O}$ catalysts activity for VOCs oxidation. Catal. Today 2008, 137, 367-372. [CrossRef]

174. Jia, M.; Bai, H.; Zhao, R.; Shen, Y.; Li, Y. Preparation of $\mathrm{Au} / \mathrm{CeO}_{2}$ catalyst and its catalytic performance for $\mathrm{HCHO}$ oxidation. J. Rare Earths 2008, 26, 528-531. [CrossRef]

175. Gennequin, C.; Lamallem, M.; Cousin, R.; Siffert, S.; Aïssi, F.; Aboukaïs, A. Catalytic oxidation of VOCs on Au/Ce-Ti-O. Catal. Today 2007, 122, 301-306. [CrossRef]

176. Pina, C.; Dimitratos, N.; Falletta, E.; Rossi, M.; Siani, A. Catalytic performance of gold catalysts in the total oxidation of VOCs. Gold Bull. 2007, 40, 67-72. [CrossRef]

177. Andreeva, D.; Petrova, P.; Sobczak, J.W.; Ilieva, L.; Abrashev, M. Gold supported on ceria and ceria-alumina promoted by molybdena for complete benzene oxidation. Appl. Catal. B Environ. 2006, 67, 237-245. [CrossRef] 
178. Gluhoi, A.C.; Bogdanchikova, N.; Nieuwenhuys, B.E. The effect of different types of additives on the catalytic activity of $\mathrm{Au} / \mathrm{Al}_{2} \mathrm{O}_{3}$ in propene total oxidation: Transition metal oxides and ceria. J. Catal. 2005, 229, 154-162. [CrossRef]

179. Andreeva, D.; Nedyalkova, R.; Ilieva, L.; Abrashev, M.V. Gold-vanadia catalysts supported on ceria-alumina for complete benzene oxidation. Appl. Catal. B Environ. 2004, 52, 157-165. [CrossRef]

180. Centeno, M.A.; Paulis, M.; Montes, M.; Odriozola, J.A. Catalytic combustion of volatile organic compounds on $\mathrm{Au} / \mathrm{CeO}_{2} / \mathrm{Al}_{2} \mathrm{O}_{3}$ and $\mathrm{Au} / \mathrm{Al}_{2} \mathrm{O}_{3}$ catalysts. Appl. Catal. A Gen. 2002, 234, 65-78. [CrossRef]

181. Tabakova, T.; Ilieva, L.; Ivanov, I.; Zanella, R.; Sobczak, J.W.; Lisowski, W.; Kaszkur, Z.; Andreeva, D. Influence of the preparation method and dopants nature on the WGS activity of gold catalysts supported on doped by transition metals ceria. Appl. Catal. B Environ. 2013, 136-137, 70-80. [CrossRef]

182. Lee, D.-S.; Chen, Y.-W. The mutual promotional effect of $\mathrm{Au}-\mathrm{Pd} / \mathrm{CeO}_{2}$ bimetallic catalysts on destruction of toluene. J. Taiwan Inst. Chem. Eng. 2013, 44, 40-44. [CrossRef]

183. Suib, S.L. New and Future Developments in Catalysis; Elsevier: Amsterdam, The Netherlands, 2013.

184. Ma, W.J.; Huang, Q.; Xu, Y.; Chen, Y.W.; Zhu, S.M.; Shen, S.B. Catalytic combustion of toluene over Fe-Mn mixed oxides supported on cordierite. Ceram. Int. 2013, 39, 277-281. [CrossRef]

185. Aguero, F.N.; Morales, M.R.; Duran, F.G.; Barbero, B.P.; Cadús, L.E. MnCu/cordierite monolith used for catalytic combustion of Volatile Organic Compounds. Chem. Eng. Technol. 2013, 36, 1749-1754. [CrossRef]

186. Zhao, F.; Zhang, G.; Zeng, P.; Yang, X.; Ji, S. Preparation of $\mathrm{Cu}_{\mathrm{x}} \mathrm{Co}_{1-\mathrm{x}} / \mathrm{Al}_{2} \mathrm{O}_{3} /$ Cordierite Monolithic Catalysts and the Catalytic Combustion of Toluene. Chin. J. Catal. 2011, 32, 821-826. [CrossRef]

187. Zhou, X.Y.; Lai, X.X.; Lin, T.; Feng, J.; Hou, Z.Y.; Chen, Y.Q. Preparation of a monolith $\mathrm{MnO}_{\mathrm{x}}-\mathrm{CeO}_{2} / \mathrm{La}^{-} \mathrm{Al}_{2} \mathrm{O}_{3}$ catalyst and its properties for catalytic oxidation of toluene. New J. Chem. 2018, 42, 16875-16885. [CrossRef]

188. Campbell, L.E.; Sanders, M.W. Sequential Adsorptive Capture and Catalytic Oxidation of Volatile Organic Compounds in a Reactor Bed. U.S. Patent US 6033638A, 20 March 1998.

189. Nguyen, P.H.; Chen, J.M.; Lapadula, G.D.; Furbeck, H.J. Method for the Catalytic Oxidation of VOC/CO in the Presence of Organosilicate Compounds. EP0993857B1, 16 October 1998.

190. Zhou, Y.H.; Ye, H.Q.; Cao, Z.; Jin, Y.S. Cordierite-Based Monolithic Catalyst without Coating Layer, and Preparation and Application Thereof. Chinese Patent CN101244386A, 24 March 2008.

191. Thompson, D.T. Perspective on industrial and scientific aspects of gold catalysis. Appl. Catal. A Gen. 2003, 243, 201-205. [CrossRef]

192. Bond, G.C.; Louis, C.; Thompson, D.T. Catalysis by Gold; Imperial College Press: London, UK, 2006.

193. Wei, D.; Vanderspurt, T.H.; Obee, T.N.; Hay, S.O.; Schmidt, W.R. Air Purification System Comprising Gold/Titanium Dioxide Photocatalyst. Chinese Patent CN100503045C, 19 June 2003.

194. Baker, J.A.; Kellie, T.F.; Brenner, R.E. Oxidation of Volatile Organic Compounds in Electrographic Printing. U.S. Patent US-0977978, 2004.

195. Haruta, M. When Gold Is Not Noble: Catalysis by Nanoparticles. Chem. Rec. 2003, 3, 75-87. [CrossRef]

196. Nieuwenhuys, B.E.; Gluhoi, A.C.; Rienks, E.D.L.; Weststrate, C.J.; Vinod, C.P. Chaos, oscillations and the golden future of catalysis. Catal. Today 2005, 100, 49-54. [CrossRef]

197. Azalim, S.; Brahmi, R.; Agunaou, M.; Beaurain, A.; Giraudon, J.M.; Lamonier, J.F. Washcoating of cordierite honeycomb with Ce-Zr-Mn mixed oxides for VOC catalytic oxidation. Chem. Eng. J. 2013, 223, 536-546. [CrossRef]

198. Agrafiotis, C.; Tsetsekou, A.; Stournaras, C.J.; Julbe, A.; Dalmazio, L.; Guizard, C. Evaluation of sol-gel methods for the synthesis of doped-ceria environmental catalysis systems. Part I: Preparation of coatings. J. Eur. Ceram. Soc. 2002, 22, 15-25. [CrossRef]

199. Sedjame, H.J.; Brahmi, R.; Lafaye, G.; Barbier, J.; Fontaine, C. Influence of the formulation of catalysts deposited on cordierite monoliths for acetic acid oxidation. CR CHIM 2018, 21, 182-193. [CrossRef]

200. Huang, Q.; Yan, X.; Li, B.; Chen, Y.; Zhu, S.; Shen, S. Study on catalytic combustion of benzene over cerium based catalyst supported on cordierite. J. Rare Earths 2013, 31, 124-129. [CrossRef]

201. Jiang, L.; Yang, N.; Zhu, J.; Song, C. Preparation of monolithic Pt-Pd bimetallic catalyst and its performance in catalytic combustion of benzene series. Catal. Today 2013, 216, 71-75. [CrossRef]

202. Papavasiliou, A.; Tsetsekou, A.; Matsouka, V.; Konsolakis, M.; Yentekakis, I.V.; Boukos, N. Development of a Ce-Zr-La modified $\mathrm{Pt} / \gamma-\mathrm{Al}_{2} \mathrm{O}_{3}$ TWCs' washcoat: Effect of synthesis procedure on catalytic behaviour and thermal durability. Appl. Catal. B Environ. 2009, 90, 162-174. [CrossRef]

203. Liotta, L.F.; Longo, A.; Pantaleo, G.; di Carlo, G.; Martorana, A.; Cimino, S.; Russo, G.; Deganello, G. Alumina supported $\mathrm{Pt}(1 \%) / \mathrm{Ce}_{0.6} \mathrm{Zr}_{0.4} \mathrm{O}_{2}$ monolith: Remarkable stabilization of ceria-zirconia solution towards $\mathrm{CeAlO}_{3}$ formation operated by $\mathrm{Pt}$ under redox conditions. Appl. Catal. B Environ. 2009, 90, 470-477. [CrossRef]

204. González-Velasco, J.R.; Gutiérrez-Ortiz, M.A.; Marc, J.L.; Botas, J.A.; González-Marcos, M.P.; Blanchard, G. Pt/Ce ${ }_{0.68} \mathrm{Zr}_{0.32} \mathrm{O}_{2}$ Washcoated Monoliths for Automotive Emission Control. Ind. Eng. Chem. Res. 2002, 42, 311-317. [CrossRef]

205. Agrafiotis, C.; Tsetsekou, A.; Stournaras, C.J.; Julbe, A.; Dalmazio, L.; Guizard, C.; Boretto, G.; Debenedetti, M.; Parussa, F. Evaluation of sol-gel methods for the synthesis of doped-ceria environmental catalysis systems: Part II. Catalytic activity and resistance to thermal aging. Appl. Catal. B Environ. 2001, 34, 149-159. [CrossRef]

206. Dang, Z.; Singh, N.; Morrill, M.; Cullen, G. Oxidation Catalyst and Method for Destruction of CO, VOC and Halogenated VOC. U.S. Patent US8475755B2, 24 August 2009.

207. Roark, S.E. Application of Catalysts for Destruction of Organic Compounds in Liquid Media. U.S. Patent US-7329359-B2, 20 December 1999. 
208. Princivalle, A.; Aubert, D.; Guizard, C.; Kaper, H.; Klotz, M. Exhaust Gas Treatment Catalyst. WO2013088091, 14 December 2012.

209. Roark, S.E.; White, J.H. Catalysts for Low-Temperature Destruction of Volatile Organic Compounds in Air. U.S. Patent US6458741B1, 20 December 1999.

210. Scott, Z.M.; Cristian, L.; Mohit, U. Catalyst and Method for Oxidizing Oxygen-Containing Organic Compounds in Waste Gas. U.S. Patent US-0730730, 15 October 1996.

211. Roark, S.E.; White, J.H. Catalysts and Methods for Low-Temperature Destruction of VOCs in Air and Selective Removal of CO. WO2001045833, 20 December 2000.

212. Ziebarth, M.S.; Libanati, C.; Uberoi, M. Catalyst and Method for Oxidizing Oxygen-Containing Organic Compounds in Waste Gas. U.S. Patent US5882616A, 09 June 1995.

213. Cutler, W.A.; Tao, T.; Torns, J.M. Structured Materials for Purification of Liquid Streams and Method of Making and Using Same. U.S. Patent US6200483B1, 08 October 1998.

214. Chandler, G.R.; Flanagan, K.A.; Phillips, P.R.; Schofield, P.; Spencer, M.L.W.; Strutt, H.M. Method of Coating a Monolith Substrate with Catalyst Component. WO2011080525A1, 04 January 2010.

215. Addiego, W.P.; Teo, J.S.K.; Teh, S.P.; Zhong, Z. Nanosized Gold Catalysts for CO Oxidation and Water Gas Shift Reactions. WO2011106213, 16 February 2011.

216. Holz, M.C.; Tolle, K.; Muhler, M. Gas-phase oxidation of ethanol over $\mathrm{Au} / \mathrm{TiO}_{2}$ catalysts to probe metal-support interactions. Catal. Sci. Technol. 2014, 4, 3495-3504. [CrossRef] 